Portland State University

PDXScholar

1994

\title{
The Role of the Chinese News Media in the 1989 Pro-democracy Movement
}

Mei Liao

Portland State University

Follow this and additional works at: https://pdxscholar.library.pdx.edu/open_access_etds

Part of the Chinese Studies Commons, and the Mass Communication Commons Let us know how access to this document benefits you.

Recommended Citation

Liao, Mei, "The Role of the Chinese News Media in the 1989 Pro-democracy Movement" (1994). Dissertations and Theses. Paper 4378.

https://doi.org/10.15760/etd.6262

This Thesis is brought to you for free and open access. It has been accepted for inclusion in Dissertations and Theses by an authorized administrator of PDXScholar. Please contact us if we can make this document more accessible: pdxscholar@pdx.edu. 


\section{THESIS APPROVAL}

The abstract and thesis of Mei Liao for the Master of Science in Speech Communication were presented April 19, 1994, and accepted by the thesis committee and the department.

COMMITTEE APPROVALS :

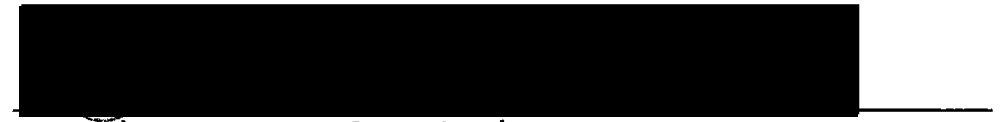

LesIie T. Good, Chair

DEPARTMENT APPROVAL:

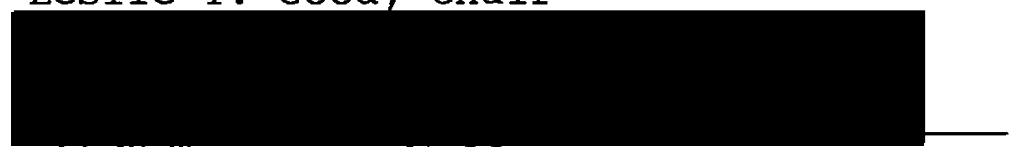

Stephęn A. Kosokoff

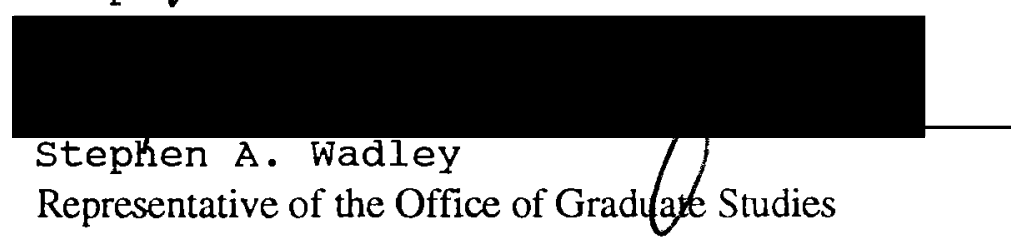

Stepheh A. Kosokoff, Chair

Department of Speech Communication

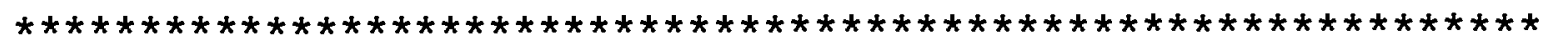

ACCEPTED FOR PORTLAND STATE UNIVERSITY BY THE LIBRARY

by

on

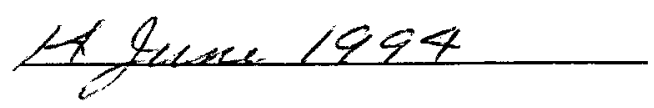




\section{ABSTRACT}

An abstract of the thesis of Mei Liao for the Master of Science in speech Communication presented April 19, 1994.

Title: The Role of the Chinese News Media in the 1989 Prodemocracy Movement.

This thesis examines the role of the chinese news media in the 1989 pro-democracy movement. The three functions of this thesis are: 1) to provide evidence of changes in the pro-democracy movement; 2) to identify corresponding changes in the press coverage of the movement; 3 ) to examine what relationship exists between changes in the movement and changes in the press coverage of the movement.

Research data for changes in the pro-democracy movement are drawn from published accounts of the movement available in the U.S. The data for changes in the press coverage of the movement are obtained from the Chinese official newspaper, the People's Daily.

Historical research and content analysis are adopted as research methods in this study. Historical research is used to gather evidence of changes in the pro-democracy movement. Content analysis is employed to collect information about changes in the press coverage of the movement.

Research findings show that the Chinese news media played different roles in the pro-democracy movement during the 
spring of 1989. At the beginning, the news media may have undermined the movement by negatively framing it as the Communist Party desired. In the second research period, the news media broke away from government control and may have played a role in advancing the movement by framing it in neutral and positive ways. In the third research period, the news media's role was complex. The media covered the prodemocracy movement both negatively and positively. In the last research period, after the movement was suppressed by the government, the news media played a role in condemning the pro-democracy movement by using both negative frames and the number-disparaging term "a handful of people" to refer to the movement.

In summary, the Chinese news media played different roles ranging from being totally subservient to the official line, to being in support of the movement. 
THE ROLE OF THE CHINESE NEWS MEDIA IN

THE 1989 PRO-DEMOCRACY MOVEMENT

BY

MEI LIAO

A thesis submitted in partial fulfillment of the requirements for the degree of

\author{
MASTER OF SCIENCE \\ in \\ SPEECH COMMUNICATION
}

Portland State University

1994 
ACKNOWLEDGMENTS

It would have been impossible for me to finish this thesis without the help of many people.

A special thank goes to Leslie Good for her patience, guidance and expertise.

I'm especially grateful to steve Kosokoff, David Wrench, and stephen Wadley for sharing their valuable time and experiences with me.

A true heartfelt and special thank goes to my best friend, Prue Douglas, for her precious time and continuous encouragement when quitting seemed so appealing to me.

I'm particularly thankful to Franny French for her invaluable help. Her commitment to quality, accuracy, and detail was absolutely indispensable to the accomplishment of this project.

I owe a special debt of gratitude to all of my friends and schoolmates who helped me in the process of data collection.

Finally, I'd like to thank my husband, Jie sun, for his understanding and support during the entire period that I was working on my thesis. 
DEDICATED TO

my parents who have always been the driving force behind my perseverance and excitement in everything $I$ do 
TABLE OF CONTENTS

PAGE

ACKNOWLEDGEMENTS $\ldots \ldots \ldots \ldots \ldots \ldots \ldots \ldots \ldots \ldots \ldots \ldots \ldots \ldots$

LIST OF TABLES $\ldots \ldots \ldots \ldots \ldots \ldots \ldots \ldots \ldots \ldots \ldots$ vi

LIST of FIGURES $\ldots \ldots \ldots \ldots \ldots \ldots \ldots \ldots \ldots \ldots \ldots \ldots \ldots \ldots$ CHAPTER

The Chinese Pro-democracy Movement

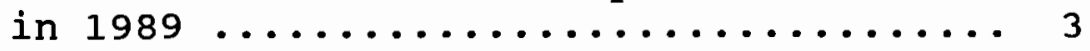

The Nature and objectives of the Chinese News Media ................... 4

The Chinese News Media and Sociopolitical Movements .............. 6

structure of This study $\ldots \ldots \ldots \ldots \ldots \ldots 7$

II LITERATURE REVIEW $\ldots \ldots \ldots \ldots \ldots \ldots \ldots \ldots \ldots$

What is News? $\ldots \ldots \ldots \ldots \ldots \ldots \ldots \ldots$

Framing the News $\ldots \ldots \ldots \ldots \ldots \ldots$

News Media and Socio-political Movements 12

The role of the Chinese Media in Sociopolitical Movements .............. 13

Research Questions ............... 20

III Research Procedures $\ldots \ldots \ldots \ldots \ldots \ldots \ldots \ldots 21$

Research Methods .............. 21

Research Data ................ 24

Research Period ................ 25 
Coding Categories .............. 26

Data Collection .............. 28

IV FINDINGS/ANALYSIS $\ldots \ldots \ldots \ldots \ldots \ldots \ldots \ldots \ldots$

Research Findings ............. 30

Changes in the Pro-democracy Movement... 31

Changes in the Press Coverage of the

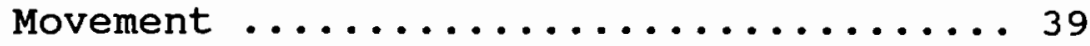

Corresponding Changes Between the

Movement and the Press Coverage of it .. 52

$\mathrm{V} \quad$ CONCLUSION/IMPLICATIONS $\ldots \ldots \ldots \ldots 6$

Introduction $\ldots \ldots \ldots \ldots \ldots \ldots \ldots$

Summary of Research Findings .......667

Conclusions $\ldots \ldots \ldots \ldots \ldots \ldots \ldots \ldots \ldots$

Limitations and Implications ....... 74

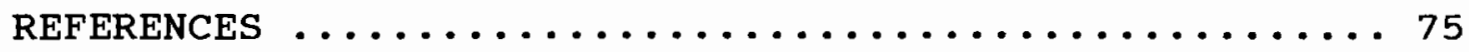

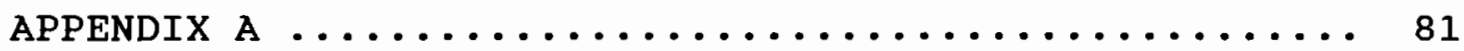




\section{LIST OF TABLES}

TABLE

PAGE

I Summary of Attention to the Movement --

$4 / 15 / 89$ to $6 / 20 / 89 \ldots \ldots \ldots \ldots \ldots \ldots$

II Symbolic Terms of the Movement --

$4 / 15 / 89$ to $5 / 3 / 89 \ldots \ldots \ldots \ldots \ldots \ldots 45$

III Symbolic Terms of the Movement --

$5 / 4 / 89$ to $5 / 19 / 89 \ldots \ldots \ldots \ldots . \ldots 47$

IV Symbolic Terms of the Movement --

$5 / 20 / 89$ to $6 / 3 / 89 \ldots \ldots \ldots \ldots \ldots 48$

V Symbolic Terms of the Movement --

$6 / 4 / 89$ to $6 / 20 / 89 \ldots \ldots \ldots \ldots \ldots \ldots$

VI Summary of Symbolic Terms of the Movement --

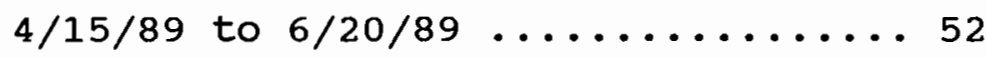




\section{LIST OF FIGURES}

FIGURE

PAGE

1. Development of the Pro-democracy Movement $4 / 15 / 89$ to $6 / 20 / 89 \ldots \ldots \ldots \ldots \ldots \ldots \ldots \ldots \ldots$

2. Attention to the Movement

$4 / 15 / 89$ to $5 / 3 / 89 \ldots \ldots \ldots \ldots \ldots \ldots$

3. Attention to the Movement

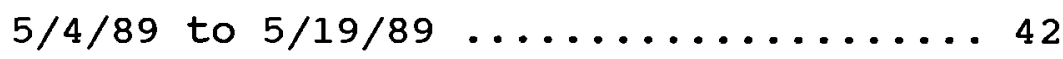

4. Attention to the Movement

$5 / 20 / 89$ to $6 / 3 / 89 \ldots \ldots \ldots \ldots \ldots \ldots \ldots . \ldots 43$

5. Attention to the Movement

$6 / 4 / 89$ to $6 / 20 / 89 \ldots \ldots \ldots \ldots \ldots \ldots 4$

6. Correspondence Between the Movement and the

Press Coverage $4 / 15 / 89$ to $5 / 3 / 89 \ldots \ldots 5$

7. Correspondence Between the Movement and the

People's Daily's Attitude towards it

(negative terms) $4 / 15 / 89$ to $5 / 3 / 89 \ldots 54$

8. Correspondence Between the Movement and the

People's Daily's Attitude towards it

(a handful of people) $4 / 15 / 89-5 / 3 / 89 \ldots 55$

9. Correspondence Between the Movement and the

Press Coverage $5 / 4 / 89$ to $5 / 19 / 89 \ldots \ldots 6$

10. Correspondence Between the Movement and the

People's Daily's Attitude towards it 
(neutral terms) $5 / 4 / 89$ to $5 / 19 / 89 \ldots 58$

11. Correspondence Between the Movement and the

People's Daily's Attitude towards it (positive terms) $5 / 4 / 89$ to $5 / 19 / 89 \ldots 59$

12. Correspondence Between the Movement and the Press Coverage $5 / 20 / 89$ to $6 / 3 / 89 \ldots 60$

13. Correspondence Between the Movement and the People's Daily's Attitude towards it (negative terms) $5 / 20 / 89$ to $6 / 3 / 89 \ldots 61$

14. Correspondence Between the Movement and the People's Daily's Attitude towards it (a handful of people) 5/20/89-6/3/89 .. 62

15. Correspondence Between the Movement and the People's Daily's Attitude towards it (neutral terms) $5 / 20 / 89$ to $6 / 3 / 89 \ldots 63$

16. Correspondence Between the Movement and the People's Daily's Attitude towards it (positive terms) $5 / 20 / 89$ to $6 / 3 / 89 \ldots 64$ 
CHAPTER I

INTRODUCTION

\section{THE PRO-DEMOCRACY MOVEMENT}

China experienced great changes after the founder of the People's Republic, Mao Zedong, died in 1976. After a few years of transition under the leadership of Hua Guofeng (Mao Zedong's anointed successor as Party chairman and state premier), China entered the era of Deng Xiaoping. Shortly after his return to power, Deng began to reform China's economic structure. The rigid policies and tight political control of the Mao-era were soon replaced by Deng's pragmatic politics, known as the "open-door policy." After ten years of trial, the new policy brought about dramatic changes in China. The increase in average income of the people from 1977 to the present has been greater than in the entire period from 1949 to 1977 (Ethridge, 1990). The living standard of the Chinese people has been greatly improved. For example, in 1989, most urban families and some rural families were able to obtain modern equipment such as television sets, refrigerators, and other electronic products, while ten years ago few people could afford them (Chan, 1989).

At the same time that this material progress was 
underway, some negative elements in Chinese society came to the surface. Traditional values were declining, and corruption among party members and their families was rampant. Government officials' profiteering, speculation, and other factors led to an unprecedented inflation rate of 18.5 percent (Mu \& Thompson, 1989). The economic gains people had enjoyed in the previous years were quickly offset by price increases in 1989, when many began to suffer from deteriorating living standards. Dissatisfaction with the uneven share of profit and resentment of distorted social reality were on the rise.

In April, 1989, people saw their opportunity: taking advantage of the death of reformist Hu Yaobang, people took to the streets to voice their dissatisfaction with official corruption and the Chinese government's inability to cope with the changes and challenges the open-door policy had brought. The public outcry in Beijing quickly spread across the whole country, resulting in a spontaneous mass protest. The movement started in mid-April 1989, and ended in early June, 1989. It was initiated by college students in Beijing. In early May, people from many walks of society-teachers, workers, journalists, shop assistants and citizens--joined the movement. The Hong Kong newspaper Min Pao estimated that two million people demonstrated on May 17, 1989 (June Fourth, 1989). The movement was not simply a student movement; rather it became the people's pro-democracy 
movement. For more than six weeks in May, students occupied Tiananmen Square, which is the symbol of authority for the Communist Party. For the first time since 1949, people took to the streets in protest against the government. On June 4 th, 1989, out of fear of not being in control of the situation, the government repressed the movement.

Although this large-scale socio-political movement was short-lived, the effect it had on Chinese society was significant and far-reaching. It was the first time that the Chinese people challenged the communist establishment in the form of mass demonstration. It was also the first time in the history of the People's Republic that journalists, who worked for the official news organizations, called en-masse for press reform while linking themselves with a student protest.

\section{THE CHINESE NEWS MEDIA}

The Nature and Objectives of the Media

According to Siebert, Peterson and Schramm (1976), there are four basic types of news media that correspond to the social and political systems within which they operate. They are: Authoritarian, libertarian, social responsibility, and soviet-totalitarian. These four categories of news media systems are not mutually exclusive in the sense that some news media have overlapping characteristics. For instance, the U.S. news media represent practice of both libertarian 
and social responsibility principles. The Chinese news media are a blend of both authoritarian and Soviet-totalitarian media philosophy and practice.

A brief look at what characterizes both authoritarian and totalitarian media systems will illustrate why the Chinese news media fit into these categories.

A news media system is recognized as authoritarian if 1) it is based on the philosophy of absolute power of a monarch, the government, or both; 2) it supports and advances the policies of the government in power and serves the state; 3 ) it is controlled and guided by the government; 4) only those in power have access and means to use and manipulate the operation of the media system (Siebert, Peterson \& Schramm, 1976$, p. 7$)$.

A news media system is based on a Soviet-totalitarian paradigm if 1 ) it is modeled on, and developed from MarxistLeninist thought; 2) it functions to achieve the success of socialist ideals and to strengthen the dictatorship of the party; 3 ) it is state-owned and tightly controlled by the government; 4) it is not permitted to criticize the party objectives and those in power.

After 1949, the Chinese news media were essentially a modified Soviet model which were guided by fundamental principles of Marxist, Leninist, and Maoist views. Maoist views, according to the definition given by the central Committee of the Chinese Communist Party, were a combination 
of Marxism, Leninism, and the concrete reality of the Chinese society (Hsu, 1990). The Chinese news medium, as defined by Mao in 1937, is "powerful weapon to unite and educate people, to attack and to wipe out the enemy....It should serve the purpose of proletarian politics" (Mao, 1966, p. 158). Mao's definition of the news medium has informed the Party's guidelines and the direction of the Chinese news media ever since.

Since 1949, the news media have been tightly controlled and effectively used as the Party's powerful tool to promote its objectives, to unify public opinion, to control social thinking, and to strengthen the proletarian dictatorship. The entire Chinese media system is organized and directed to fulfill these tasks. As Terrell (1984) stated,

Each of China's mass communication systems is operated as a government agency. Whether under the auspices of a local, district, regional or national agency, they are used to promote the Party's objectives. Media workers are assigned to their positions by officials designated by the Party, and their performance on and off the job is subject to Party review at all times (p.147).

As a result of this type of control and supervision, the news media in China became simply a mouthpiece of the Communist Party.

The Chinese News Media and Socio-Political Movements

In pluralist democratic societies, autonomous political and social movements are a common feature acceptable to the State, but such movements are seen as dangerous to the power 
establishment of an authoritarian government (Saich, 1990). All authoritarian governments claim to represent the interest of the majority of the people, but since autonomous organizations constitute a direct challenge to the "leading position" of an authoritarian government, that government will seek to crush any autonomous movements and denounce them as "counterrevolutionary" movements (Saich, 1990). Such is the case with the 1989 Chinese pro-democracy movement.

During the past forty-year communist rule in China all Chinese political and social movements have been pre-planned and maneuvered from the top down; for example, the Hundred Flowers Movement in 1956, the Anti-rightists Movement in 1957, the Great Leap Movement in 1958, the Cultural Revolution Movement from 1966 to 1977, the Anti-Confucian Movement in 1972, and the Anti-bourgeois Liberalization Movement in 1983 and 1987, were all pre-planned movements. These movements were mobilized by the Party for the purpose of garnering large-scale support for policy changes (Saich, 1990). Often, the result of such movements was the ousting of those who were the targets of the movements.

The Chinese news media have played an active role in initiating political movements (Lee, 1990). The People's Daily, the Party's official newspaper, incited many of these movements by publishing articles proclaiming the worth of the movements. In the forty-year history of communist rule, the media have successfully played their part, assigned by 
the Party, in attacking those who are not loyal to the Party. The Chinese news media played different roles in reporting the 1989 pro-democracy movement at different periods. At the beginning, the media downplayed the movement by negatively framing it, as the Party desired. As the movement developed in the second research period, May 4, 1989 to May 19, 1989 (see Chapter Three for a detailed discussion), the media may have played a role in pushing forward the movement by using neutral and positive frames in covering it. For about two weeks in May, 1989, the media broke away from government control and reported truthfully the nature and goals of the movement. In the third research period (May 20, 1989 to June 3, 1989), after martial law was imposed, the media's role was complex. The media reported the movement both negatively and positively for a few days. In the last research period (June 4, 1989 to June 20, 1989), after the government's suppression of the movement, the media played a role in condemning it as well, by using both negative frames and terms of disparagement to refer to the movement.

\section{THE STRUCTURE OF THIS STUDY}

This research is intended to analyze the function of the Chinese news media in the 1989 pro-democracy movement. To be more specific, the central interest of this research is to focus on what role the Chinese news media may have played in 
the pro-democracy movement. Did the news media merely follow the Part." guidelines in reporting the movement? To what extent $d_{\perp} d$ the news media reflect the nature and purpose of the movement? Did the news media function to propel the progress of the movement, or did they try to debilitate and distract the mass movement as the communist Party desired? These are the initial questions on which the focus of this study rests.

The research period, adopted from Sun (1992), is from April 15, 1989 to June 20, 1989 (a total of 66 days). The research data are obtained from books about the pro-democracy movement and the official Chinese newspaper, the People's Daily. This research includes changes in the pro-democracy movement, changes in the press coverage of the movement and the corresponding changes between the chinese news media and the pro-democracy movement.

The following chapters include a literature review, research procedures, findings, and conclusions. The literature review, which is the theoretical foundation for this study, is presented in chapter Two. Research methods, data collection, and specific procedures are discussed in Chapter Three. The findings of the research are illustrated and interpreted in Chapter Four. Conclusions, limitations, and implications are presented in chapter Five. 
CHAPTER II

\section{THEORETICAL FOUNDATION}

\section{WHAT IS NEWS?}

The question "what is news?" is open to debate. Early theorists perceived news as a mirror reflecting reality. In their view, news was what happened in the past or what is happening in actual life in the present (Lang \& Lang, 1953). Such perspectives were largely accepted through the 1950 s and the 1960s. But from the 1970s on, scholars in mass communication began to challenge this view. Tuchman (1978) refuted the preceding perspective with a new concept of news as a constructed reality. News was not an actual or mirrored picture of reality, but a frame through which the social world was routinely reshaped and purposely put together.

FRAMING THE NEWS

In her book, Making News, Tuchman (1978) explains the concept of media frames when she writes:

News is a window on the world. Through its frames, Americans learn of themselves and others, of their own institutions, leaders, and life styles, and those of other nations and their peoples.... But like any frame that delineates a world, the news frame may be considered problematic. The view through a window depends on whether the window is large or small, has many panes or few, whether the glass is opaque or clear, whether the window faces 
a street or a backyard... (p. 1).

Tuchman uses the analogy of news as a window frame, but warns that the characteristics of the window--its size and placement--limit the scope of what may be seen and limit one's perspective in terms of what one sees. The operative features of news frames are that they both conceal and reveal, produce and limit meaning; they "give some occurrences a public character while preventing others from becoming public information" (p.3). Media frames are a set of rules and guidelines that news reporters consciously or unconsciously follow, when making decisions on what to report or what not to report.

Tuchman's viewpoint is supported by Sigal (1986) when he states: "News is not what happens, but what somebody says has happened or will happen" (p.15). And again Gitlin (1980) states this opinion when he argues:

Anything could be news, for news is what newsgatherers working in news-processing organizations say is news. Therefore, it is historical and contestable; all deep social conflicts are in part conflicts over what is news (p. 268).

At the same time, Gans (1979) composes a synthesis of approaches to explaining the news. He concludes that newsreporting organizations are influenced by pressures both from inside and outside their organizations, and that what is news is determined by who is in power.

Howitt (1982) employs the concept of "gatekeeper" to explain this power process of news selection. The concept of 
gatekeeper is important for understanding how organizations operate in the process of news making. Gatekeepers have the power to decide what information can be processed into "news" and what materials cannot become "news." They let certain pieces of news go through, while keeping out certain others.

In his research, Gitlin (1980) also found certain frames regarding political movements, which include:

.trivialization (making light of movement language, dress, age, style, and goals);

- polarization (emphasizing counterdemonstrations, and balancing the antiwar movement against ultra-Right and neo-Nazi groups as equivalent "extremists");

- emphasis on internal dissension;

- marginalization (showing demonstrators as deviant or unrepresentative);

-disparagement by numbers (under-counting);

.disparagement of the movement's effectiveness (p.28).

Some of these framing devices can be applied to the present study. For the purpose of the current study, I will use and redefine four of Gitlin's framing devices. I redefine 1) trivialization as downplaying the meaning and significance of the pro-democracy movement; 2) polarization as a way to offset the effectiveness of the movement; 3 ) marginalization as presenting demonstrators as counterrevolutionary; 4) disparagement by number as undercounting the demonstrators (for a detailed discussion, see Chapter Three of this study). 


\section{NEWS MEDIA AND SOCIO-POLITICAL MOVEMENTS}

The news media and political movements are intertwined social phenomena. When people with similar demands express their desires together, a possible social movement is developed. But any given social movement must appeal to the public, and make the public aware of the significance and goals of the movement. One important strategy that people use to start a social movement is to create "news events" (Gitlin, 1980).

News media play an active and instrumental role in social and political movements, supporting the authorities by giving them preferred access, while undermining organizations in political opposition by giving them unfavorable coverage (Gitlin, 1980). In his 1980 research of the students for a Democratic Society (SDS) movement in 1965 in America, Gitlin studied the frames that The New York Times and CBS used in reporting SDS's activities, and concluded that SDS's reputation for illegality was established by these news agencies.

Parenti (1986) provides a similar viewpoint in stating:

The most important effect of the news media is that they set the issue agenda for the rest of us, choosing what to emphasize and what to ignore or suppress, in effect, organizing much of our political world for us (p. 21).

News media are so powerful in defining, shaping, and creating images for political or social movements that, 
... people find themselves relying on the media for concepts, for images of their heroes, for guiding information, for emotional charges, for a recognition of public values, for symbols in general, even for language (Gitlin, 1980, p.1).

The public, as Gitlin suggests, understands any political or social movement through the media's definition and depiction of that movement. The image of a political or social movement is then created by the news media. Gitlin (1980) writes:

Media images also become implicated in a movement's self-images; media certify leader and officially noteworthy "personalities"; indeed, they are able to convert leadership into celebrity, something quite different. The forms of coverage accrete into systematic framing, and this framing, much amplified, helps determine the movement's fate (p.3).

News media not only shape and define political movements, they also help advance any given movement. In 1989, the Chinese news media played an important role in pushing forward the pro-democracy movement. A detailed discussion of the relationship between the Chinese news media and the 1989 pro-democracy movement is provided in Chapter Four of this study.

ROLE OF THE CHINESE MEDIA IN SOCIO-POLITICAL TERMS

Under the Communist Party's control, the Chinese news media have played different roles in the fifty-year history of the People's Republic. The primary function of the Chinese news media is to propagate the Party's policies (Nathan, 1985). In a speech to the editorial staff of the 
Shansi-Suiyuan Daily in 1948, Mao (1969) wrote:

The role and power of newspapers consists in their ability to bring the Party program, the Party line, the Party's general and special policies, its tasks and methods of work before the masses in the quickest and most extensive way (p.241).

As a mouthpiece of the Party, the news media act quickly and efficiently in transmitting the Party's policies. Mao wrote a letter to some local officials in 1958 stating: "When it comes to the work of the whole province and all the people, a newspaper has the greatest effectiveness in organizing, stimulating, criticizing, and motivating" (Mao, 1969 , p. 24$)$.

The second mission of the chinese news media is to impose ideological reform on the people, stressing "unified thinking" (Chu, 1981). In other words, Chu implies that this function of the news media aims to control the people's minds so that people will think exactly as the Party does. In his book on Our Party's Journalist Work, Hu Yaobang says:

The fundamental interest of our people is uniform, and the political orientation and basic policies of the Party Central Committee and the state Council represent the interest of the people. It is inevitable and natural for the masses to speak in one voice about these fundamental issues, while it is unnatural to make a "different" sound toward them (China Daily, April 15, 1985 ).

In order to unify people's thinking, the Communist Party has adopted the traditional chinese authoritarian ruling strategy (Mu \& Thompson, 1989). The traditional way of ruling in China had been to have people listen to and speak with one voice. Different ideas or personal opinions were 
considered harmful to the ruling regime, and therefore had to be suppressed. People had to follow whatever the ruling class said.

After the Communist Party took power in 1949, people had to abide by the Party's thinking. Those people who dared to express different views were punished. For example, thousands of intellectuals who had criticized the government in 1957 were denounced as "rightists," and were banished from their occupations and suffered miserably for two decades ( $Y u$, 1988). Under the Communist Party's control, the news media have played the most important role in launching large scale revolutionary propaganda, and in making the people believe in, love, and support the Party.

The third task of the Chinese news media is to serve as an instrument for the struggle for political power in the Party (Chu, 1981). This function expanded drastically during the Cultural Revolution (1966-1976) when the "Gang of Four" (Mao's wife Jiang Qing and her three senior associates, Zhang Chunqiao, Wang Hongwen, and Yao Wenyuan) tried to seize power by publishing disparaging articles against other Party members. Anybody who wanted to affect the direction of the Party or defeat a political opponent had to exert control over the news media, because they reflected the "current Party line." The news media control what people should or should not be told, and when. Therefore, the person in charge of the press has always had some political risks, for 
he can be promoted or demoted as the result of a power struggle on the top level.

The fourth function of the chinese news media is to initiate movements and policy shifts which often come after intense power struggles at the top level of the Party (Lee, 1990). The editorials of the chinese newspapers, like the one in the People's Daily on April 26, 1989, always reflect the will of those who have won the power struggle. In fact, some officials write editorials for the People's Daily to incite movements throughout the country. For instance, both the Antirightist Campaign (1957) and the Cultural Revolution (1966) were stirred up by the articles written by Mao himself in the People's Daily (Pye, 1979, p. 221).

In the history of Communist Party rule in China, at different times, the relative importance of each function of the news media has fluctuated somewhat according to prevailing political, economic, and ideological situations. The definition of the nature and objective of the news media has varied slightly, but the overriding definition has always been that the press is an integral part of the whole revolutionary machine, achieving the Party's goals, and promoting its policies. Even the late Party chief $\mathrm{Hu}$ Yaobang, who was viewed as open-minded and reformist, publicly stated that the news media had to function as "the ears and eyes" of the Party. 
Secretary $\mathrm{Hu}$ Yaobang reaffirmed totalitarian press principles by warning his nation's journalists that journalism "should reflect what the party and government say, and expose the party line and policies" (Lin \& Salwen, 1986, pp. 360-361).

Thus we can see that in China, the key factor in news selection is political significance (Mu \& Thompson, 1989). Anything that serves the Party's political objectives can be automatically newsworthy. Anything in conflict with the Party's political interest cannot be reported, no matter how interesting and important it may be to the public. When talking about the timeliness of journalism, the former Party chief Hu Yaobang made the following comment:

Journalist work should seek timeliness, but not unconditionally in all issues.... Our Party's prestige often suffers from hasty, premature reports of major news and events without necessary approval from the higher authorities... Timeliness is not hastiness and timeliness of major news is subsidiary to political task (China Daily, April 15, 1989, p.1).

To illustrate how the Chinese government selects news, Mu and Thompson (1989) state that,

...corrupt officials at higher levels were not exposed in newspapers, not because reporters do not know of such cases: many of them are open secrets, such as Deng Xiaoping's own son Deng Pufang, and Zhao Ziyang's son Zhao Dajun both being involved in "official profiteering," but because it is not in the "Party line" to report such cases involving top leaders and their family members. It seems that too often the Party confuses a monopoly on information with a "correct line" (p. 115).

Chinese news reporters also play a part in the process of news selection by censoring themselves. 


\section{Self-censorship}

There are no written rules and regulations for the news reporters to follow in the Chinese media system. Rather, the Communist Party imposes tight control over the news media by institutionalizing communist ideology. As Remington (1988) observes, with respect to journalists in the Soviet Union, "journalists in China are integrated into the political system as junior partners of the political elite, and the occupation keeps itself in line largely through internalized, implicit and self-perpetuating constraints" (p. 152).

Through years of being indoctrinated into the communist ideology, news reporters know the subtle rules of what can and cannot be reported.

Walder (1986) conducted research on the structure of Chinese factories. His research found that the Chinese government's control of the society is not only by means of terror, suppression, and secret police, it is also

... a system of reward that uses career incentives and the factory's considerable resources to reward "moral" behavior and political loyalty, as defined by the Party and management, and to penalize any opposition (p. 132).

The exchange of political loyalty for status, career opportunities and favorable treatment in other areas is done through a unit system (one's unit is the factory, office, company, school, etc., where one works). Such units control food, housing, raises, promotions at work, medical insurance, transfers, and other living necessities. The communist 
system lures people into showing political loyalty and enthusiasm for the Party's policies in exchange for personal benefits. The priority in the Party's allocation policy is based on whether a person is loyal to the Party. Walder's observation also applies to Chinese news reporters. In working for state-run mass organizations, reporters are controlled by their work units. As a result, they follow the official line for fear of losing their jobs.

Bitter lessons of past political campaigns also taught news reporters the results of not following the Party line. For example, former People's Daily reporter Liu Binyan wrote controversial articles in 1957. He was then branded as a rightist, and ostracized for nearly twenty years. Under threat, journalists have become used to reporting what the Party told them to report. As Hsiao \& Yang (1990) stated, "praising government virtues while telling lies is the easy, peaceful, protected route" (p. 116). All these factors make Chinese news reporters cautious in the process of news selection. In Polumbaum's words: "In China, journalists themselves may have acted as the most effective censors of the news" (Polumbaum, 1988, p. 55).

\section{RESEARCH QUESTIONS}

On the basis of the above literature review, I intend to pursue answers to the following research questions.

1. What are the changes in the 1989 Chinese pro- 
democracy movement? (Operationally, change is indicated by patterns of daily numbers of protests, numbers of demonstrators, and different political demands at different periods.)

2. What are the changes in the press coverage of the pro-democracy movement? (Operationally, change is measured by patterns of 1 ) attention given to the movement; 2) attitude toward the movement.)

3. Is there a relationship between the changes in the pro-democracy movement and the changes in the press coverage of the movement?

\section{SUMMARY}

Tuchman, Gans, Gitlin, and Howitt all explain that news is not a picture of reality; rather it is the product of power. This belief is exemplified by the Chinese news medium which is controlled by people in power. Chapter Three of this study will discuss the methods for measuring the changes in the pro-democracy movement and in the press coverage of the movement throughout this time of political turmoil. 
CHAPTER III

\section{RESEARCH PROCEDURES}

\section{INTRODUCTION}

The present study uses historical research and content analysis as research methods. Historical research method is used to assemble evidence of changes in the pro-democracy movement, while content analysis is used to gather information about changes in the press coverage of the movement.

According to Phifer (1961), the historical method blends data (or facts) obtained from various sources into a lucid and flowing narrative. The purpose is to

...reinterpret already known facts and present new conclusions or explanations (Rubin, Rubin \& Piele, 1986 , p. 57).

Like other research methods, historical research has its own requirements. As Stacks and Hocking (1992) state,

The historical researcher must gather primary sources of information: documents (which may include books, photographs, audiotapes, videotapes, etc.). Once the documents have been read (or heard or viewed), categoried, and scrutinized, the researcher can begin to make the interconnections between the "facts" as seen by the particular source and those that he or she can verify (p.106).

Content analysis was developed by Lazarsfeld (1948) and Berelson (1952). They completed a series of systematic 
research projects using this innovative method. Since then, content analysis has proven useful in many fields of scientific research.

Rubin and Piele (1986) define content analysis as a research method that "focuses on the characteristics of the content of the communication" (p.63). In other words, characteristics of the content carry symbolic meanings of messages. The content of communication indicates the subject of study, be it newspapers, magazines, files, or records.

Krippendorff (1980), in his writing about content analysis and its application, states, "Content analysis is a research technique for making replicable and valid inferences from data in its context" (p.21).

Krippendorff's definition has three implications regarding its application in research. First, content analysis is a research technique. Like all other research tools, content analysis requires objective and systematic procedures to carry out the actual research. Second, content analysis should generate replicable and valid inferences. In its general sense, any research findings, as a result of using content analysis, should stand the test of replication in other similar research. Third, the purpose of using content analysis is to provide new insights, knowledge, and "facts."

Krippendorff (1980) provides a theoretical framework which contains six elements: 
1) data as communicated to the researcher

2) context of the data

3) how the analyst's knowledge frames his reality

4 ) the target of a context analysis

5) inference as the basic intel lectual task

6 ) validity as the ultimate criteria of success (p.21)

First, when using content analysis, the researcher must be clear which data he will analyze, how he will define them, and from which population the data will be drawn. Second, the researcher must define the boundaries beyond which its analysis does not extend. Third, the researcher's own knowledge and interest determines the construction of the context within which inferences are made. Fourth, the aim of the inferences must be clearly stated. Fifth, conclusions of the research are drawn from aggregated findings. Finally, the researcher must provide and specify detailed references and sources of his research for the readers to validate his results.

In summary, the purpose of content analysis is to obtain meaningful data from the content of written materials which contain symbols, and to present readers with symbolic meanings of messages carried in the symbols. In order to obtain meaningful information from any given content, consistent and systematic procedures must be followed. Using carefully designed coding categories is one way to maintain consistency in research. 
RESEARCH DATA

The data concerning changes in the pro-democracy movement were obtained from publications about the movement available in the United States. These publications include, for example, China's Unfinished Revolution, Crisis at Tiananmen: Reform and Reality in Modern China, Almost A Revolution, Tell the World, June Fourth, Tiananmen Square. Most of these books are written by people who witnessed the movement in the spring of 1989.

Research data regarding changes in the press coverage of the movement were drawn from the chinese newspaper, the People's Daily (Renmin Ribao). This newspaper was selected because it is the most important and authoritative government newspaper in China (Chu, 1984; Terrell, 1984; Mu \& Thompson, 1989). It is the "documentation of the Party Central Committee" (Mu \& Thompson, 1989, p. 117). The People's Daily establishes the primary agenda for the news presentation and editorial comment for all other Chinese newspapers. In Terrell's words, "Newspapers and televisions at the provincial and city levels, tend to follow the lead of the People's Daily" (Terrell, 1984, p. 3) .

Founded by the Chinese Communist Party on June 15, 1948, the People's Daily is directly controlled by the propaganda department of the Chinese communist Party. It has a large circulation, estimated in 1989 to be approximately 7 million (Liu, 1990). Copies are distributed to all schools, 
government offices, factories, companies, and production teams in the countryside.

The People's Daily is an eight-page paper which produces a four-page daily insert for the provincial and district newspapers. The content of the People's Daily is divided into four sections: (1) news, (2) Party announcements,

features on model production companies and workers, and letters to the editor regarding corruption among party officials, (4) advertisements.

In China's governmental structure, the People's Daily is a ministry-level operation; its editors have the status and prerequisites of ministry-level bureaucrats. They are often invited to important meetings of the ruling Politburo so that they will fully understand "the official line."

\section{RESEARCH PERIOD}

For this research, the daily releases of the People's Daily from April 15, 1989 to June 20, 1989 (a total of 66 days) were coded and analyzed. The movement actually ended in military intervention on June 4, 1989; however, my research covers 66 days, because the goal of this study is to trace the media reaction to the pro-democracy movement both during and after it. This period was divided into four parts (Sun, 1992):

1) April 15, 1989 --May 3, 1989 (Hu Yaobang's death and the seemingly spontaneous student demonstrations; 
2) May 4, 1989 -- May 19, 1989 (May 4th Movement Anniversary, Gorbachev's China visit, and the imposition of martial law in Beijing;

3) May 20, 1989 -- June 3, 1989 (escalation of tension, the violent ending of mass

demonstrations and the students' occupation of Tiananmen Square);

4) June 4, 1989 -- June 20, 1989 (the nationwide arrests, the media reaction and the two weeks following the movement) (p.35).

\section{CODING CATEGORIES}

The evidence demonstrating the changes in the prodemocracy movement was obtained from publications about the movement available in the United States. The number of demonstrators involved in each demonstration, the frequency with which they demonstrated, and their demographics were all recorded here. The different political demands made by the demonstrators during different periods of the movement were also collected. In this research, the number of news articles regarding the movement that appeared in the People's Daily was counted and the placement of news articles was coded as indicators to show how much attention the People's Daily gave to the movement. The frequency of symbolic terms used by the People's Daily to describe the movement in different periods was coded as an indicator to show the 
attitude that the People's Daily took towards the movement.

The framing devices Gitlin found in his 1980 research were redefined and applied to the present study. However, Gitlin's framing devices apply only to negative portrayals of a social movement. I found in this research that negative terms of the pro-democracy movement included such words as "instigators," " hooligans," " rioters," "trouble-makers," "handful of people," " turmoil," "political disturbance," "rebellion," "anti-party," " anti-socialist system" and "counterrevolutionary."

In searching for whether the People's Daily carried neutral or positive portrayals of the movement, I found that neutral terms about the pro-democracy movement included: "student movement," " student protests" and "student demonstrations." Positive terms include: "patriotic," "reasonable," "peaceful," "popular," and "nonviolent."

\section{DATA COLLECTION}

The research data, the People's Daily, were not available at Portland state University. Microfilmed copies of the newspaper were borrowed from the University of Washington. Because the microfilm was checked out for only a short period of time, all the news articles regarding the movement from April 15, 1989 to June 20, 1989 were photocopied. The actual data collection started after all the news articles were copied from the microfilm. 
To ensure the reliability of data collection, three Chinese students were invited to participate in the entire coding process. They were given instructions about the coding procedures but were not informed of the research questions. Pre-designed and copied coding sheets (see Appendix A) were given to the coders. The following was a list of rules guiding the coders in the coding process:

1) All the news articles regarding the pro-democracy movement on front pages were to be counted. All the news stories on inside pages were to be coded, whether they appeared in domestic news sections, in economy sections, in literature and art sections, or in the international news sections. Most news articles were carried on front pages and in domestic news sections. However, some of these appeared in economic and international news sections. The paragraphs of the news articles were to be coded, and the placement of the news articles was also recorded.

2) All symbolic terms describing the movement were to be counted, no matter where they appeared. Each paragraph was set to be one coding unit. Symbolic terms-- whether negative, neutral, or positive-- were to be coded only once in each coding unit. Paragraphs which contained no symbolic terms were not included in the coding process. The total number of paragraphs with symbolic terms was recorded. 
The research findings are presented and analyzed in Chapter Four. 


\section{CHAPTER IV}

\section{RESEARCH FINDINGS}

This chapter presents the research findings. First, the development of the pro-democracy movement is discussed. Then, the changes in the press coverage of the movement are illustrated and interpreted. Finally, the correspondence between changes in the movement and changes in the press coverage of the movement is presented.

Changes In The Pro-democracy Movement

As stated earlier, the data for changes in the prodemocracy movement are drawn from books about the movement available in the United States. The scope of the prodemocracy movement was measured by 1) the number of demonstrators involved in each demonstration and the frequency of demonstrating; 2) the characteristics of demonstrators; 3 ) different political demands made by demonstrators during different periods.

Graphic figures are used to illustrate, on a time line, the findings of this study. Figure 1 displays two major findings of this research. First, it shows the development of the movement, and then, it presents the scope of the movement. 
Figure 1

Development of the pro-democracy movement

$$
(4 / 15 / 89-6 / 20 / 89)
$$

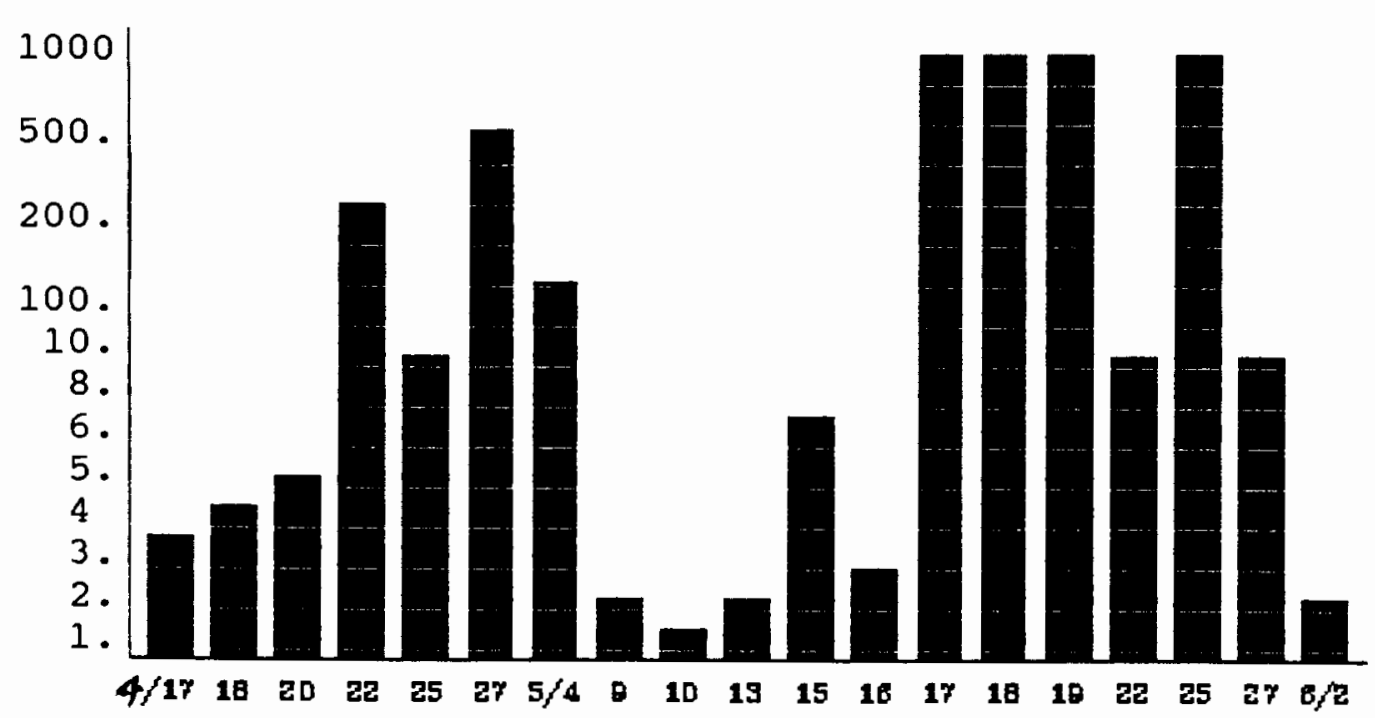

The vertical numerical unit is in thousands, displayed as unequal intervals for summary convenience. The dates on which no demonstrations took place were excluded from the figure.

As Figure 1 shows, there were six demonstrations in the first research period (April 15, 1989 to May 3, 1989). The number of demonstrators increased as the movement developed. Most demonstrators in this period were college students in Beijing, but the biggest demonstration (on April 27, 1989), in this period was one which was also joined by many Beijing citizens. On this date, the number of demonstrators reached half a million. It was the first and the largest demonstration since the foundation of the People's Republic.

In the second research period (May 4, 1989 to May 19, 1989), the frequency of demonstrations increased from six to 
nine times; and the number of demonstrators also increased greatly. Three massive demonstrations took place on May 16, 17 and 18, 1989. Each of these demonstrations reached one million. On May 4, 100,000 people joined the demonstration including workers, students, writers, citizens, shop assistants, and, for the first time, journalists of official news organizations ( $\mathrm{Liu}, 1989$ ).

In the third research period (after the imposition of martial law in Beijing), the frequency of demonstrations decreased. There were only four demonstrations in this period, however, the number of demonstrators did not decrease. On May 25, 1989, one million people marched in the streets to protest martial law. On June 2, 10,000 people demonstrated in support of the movement. This was the last demonstration that took place before the military suppression of the movement. From May 12 on, hundreds of thousands of students and citizens occupied Tiananmen Square.

In the last research period (after the military crackdown on the movement), demonstrators disappeared completely. The government began to hunt for the student leaders and leaders of autonomous organizations throughout the entire country.

After the former Party chief $\mathrm{Hu}$ Yaobang died in midApril 1989, the Federation of Beijing Student Unions (interim) (FBSUI) united the student organizations of fortyone colleges in Beijing and began to lead the movement. The 
FBSUI declared that the organization would adopt collective leadership and a representative voting system, and would embrace peaceful and legal means to pursue the goals of democracy, freedom of the press and an end to official corruption (June Fourth, 1989). The seven demands set out in the students' petition on April 18, 1989 were the guiding principles for the movement:

1) Reevaluate Hu Yaobang's achievements;

2) Reject the campaigns against "spiritual contamination," and "bourgeois liberalization;"

3) Reveal the true financial situation of the Party and state leaders, as well as that of their children;

4) Guarantee freedom of the press and allow unauthorized newspapers to exist;

5) Increase funds for education;

6) Cancel Beijing's ten regulations against demonstrations;

7) Report the real story of the student movement (Liu, 1989, p.33).

In sharp contrast to the student movements in the past ten years, students' demands this time addressed concrete economic and social problems such as inflation, official profiteering, and corruption. Their demands appealed directly to the general dissatisfaction of the common people. The students tried to win the people's support which was missing in previous student movements. 
Receiving no response from the government, the students boycotted classes and sat in at Tiananmen square. At the same time, they continued to try to have a dialogue with the government leaders. On April 20, thousands of students staged a sit-in outside Zhongnanhai, China's political center, demanding that Premier Li Peng come out and talk to them. In a police charge, several students were injured. However, official reports of the incident referred to students as "trouble-makers" who incited the incident and wounded police officers (People's Daily, April 21, 1989, p.1).

The April 20 incident made the students realize that they had to turn to freedom of the press to prevent the government from distorting their movement. They felt that if the press could accurately report the movement, people could understand and support them. But being aware of the fact that the press was under tight control of the government, and being aware of its unfavorable treatment of the previous student movements, the students published their own newspaper, News Herald, to counteract the official news media. The first issue of News Herald was so popular that it sold out quickly (Mu \& Thompson, 1989). At the same time thousands of students were sent to the streets and factories to brief people on what their movement meant and on the patriotic nature of it. They tried to convince people that their movement was justified. The movement was well 
accepted by the people in Beijing and in other cities of the country. A huge sum of money was collected for the movement from many different strata of society (Shen \& Yen, 1990).

After the publication of their own newspaper, the students continued to urge the government to hold a dialogue with them. And again the government did not pay any attention to the students' demands. On the contrary, six days later the People's Daily published an editorial accusing the students of creating "turmoil." In protest to this editorial, the FBSUI organized a huge demonstration in which half a million people participated the next day. After the massive demonstration on April 27, people from all walks of society began to take part in the movement, and it spread quickly across the entire country.

In support of FBSUI's efforts towards the dialogue, the autonomous student union of Beijing University decided to stage a limited class boycott. The organization put forward five demands as conditions for ending the class boycott:

1) that the People's Daily apologize for its April 26 editorial and give the student movement fair and objective treatment;

2) that the government recognize the autonomous student unions ;

3) that the state Council make known at once the statistics on official profiteering cases and set up an office to investigate and $f i x$ blame for official 
profiteering;

4) that the Shanghai Party Committee annul its decision and allow Qin Benli to return to office;

5) that the Beijing Municipal Government revise the ten rules of the demonstration law (June Fourth, $1989)$.

While the students were urging the government to have a dialogue with them, the journalists were also demanding a dialogue with the top officials in charge of the news media. On May 9, 1989, 1,013 journalists signed a petition to the All-China Journalists Association. The petition listed problems they saw as topics of the dialogue: 1) the Economic Herald incident in which Qin Benli was dismissed as editor-in-chief of the newspaper; 2) the news coverage of the students' activities in the past weeks, which they said was not enough and not objective, ... a failure caused by censorship and in violation of the principles set down by the Thirteenth National Congress of the Chinese Communist Party. 3) State Council spokesman Yuan Mu's statement in Beijing on April 29 that "news reporting in China is based on a system of chief editors being in charge of everything in their units," which does not conform to the facts (June Fourth, 1989, p. 51).

After the journalists' first participation in the movement on May 4, 1989, they began to report the movement in neutral and, even positive ways, especially after the 3000- 
student hunger strike on May 16, 1989 (Feigon, 1989). This time the students' demands became more focused: 1) Recant the April 26 editorial in the People's Daily and recognize the student movement as patriotic; 2) conduct an equal dialogue with students as soon as possible (Liu, 1989, p.30). The hunger-striking students won popular support from almost every segment of the society. More than 30 famous intellectuals wrote the "May Fifteen statement" in support of the students. Ten presidents of Beijing colleges and universities wrote to the government leaders urging them to talk with the students (People's Daily, May 17, p.2).

As the influence of the movement spread, non-student organizations were set up. The two most important were the Beijing Intellectuals' Association and the Beijing Workers' Autonomous Federation. To accommodate these new groups, the Consultative Joint Committee of All the Capital's Groups was formed. This committee remained the most influential until the end of the movement.

On May 17, more than one million people joined the demonstration. For the first time protesters came not as individuals but as part of work units. School teachers, factory workers, journalists, government officials, artists, and writers joined in, marching with flags and banners waving in front of them (Feigon, 1990).

Under pressure, the premier Li Peng held a televised dialogue with student leaders on May 18, 1989. At the 
meeting, Li Peng warned students to stop fasting but refused to discuss substantive issues with them.

On May 20, 1989, martial law was declared in Beijing. Thousands of people came to the streets and blocked the soldiers from entering the city. The Workers' Federation became the most active in stopping army vehicles from entering Tiananmen Square (Simmie \& Nixon, 1989). On May 30 , the Student Hunger Strike Delegation announced four demands as conditions to leave the square: 1) calling off the martial law; 2) withdrawing troops from Beijing; 3) guaranteeing that there would be no punishment afterward; 4) providing freedom of the press (Liu, 1989, p.55). The government did not respond to the demands of the hunger-strike students. The movement ended with government repression on June 4, 1989 . Although the students changed their demands at different periods, throughout the movement, there were the appeals that the just and patriotic nature of the movement be recognized by the government, and that the government hold an equal dialogue with the students. From the beginning of the movement, the students realized the importance of letting people understand the patriotic nature of the movement, as well as the legality of their autonomous student unions. By declaring the student movement to be a "counterrevolution," and a "turmoil," the government implied that the movement should not be tolerated; this provided the justification for a later crackdown on the movement. The government used 
the word "turmoil" to denigrate the movement just as it had used the word many times in the past to defame opposition (Mu \& Thompson, 1989). By using the word "turmoil," the government tried to liken the movement to the Cultural Revolution which was referred to as "ten years of turmoil" in modern Chinese history. The government tried to remind people of the horrible experience they had during that decade, and by so doing prevented people from joining the movement.

It was very important that the People's Dailv referred to the pro-democracy movement as "counterrevolutionary." "Counterrevolutionary" in chinese code implies being antiCommunist Party, anti-socialist system, and anti-People's Republic of China. By labelling the students as counterrevolutionary, the People's Daily demanded that people "take a clear-cut stand against turmoil." As William Safire pointed out, following the imposition of martial law,

Communist leaders brand all serious opposition as "counterrevolutionary." They gain, hold, and concentrate their power subtly at first, in the name of democracy, and brutally at the end, in the name of order (Ethridge, 1990, p.11).

\section{Changes In The Press Coverage of The Movement}

As stated in Chapter Three, the changes in the press coverage of the movement were measured by 1) the amount of attention the People's Daily gave to the pro-democracy movement, measured by the number of news articles related to the movement that appeared in the People's Daily and the 
placement of the articles; 2) the attitude the People's Daily took towards the pro-democracy movement, measured by counting the frequency of symbolic terms used to describe the movement in different periods.

\section{Figure 2}

Attention to the movement

$$
(4 / 15 / 89-5 / 3 / 89)
$$

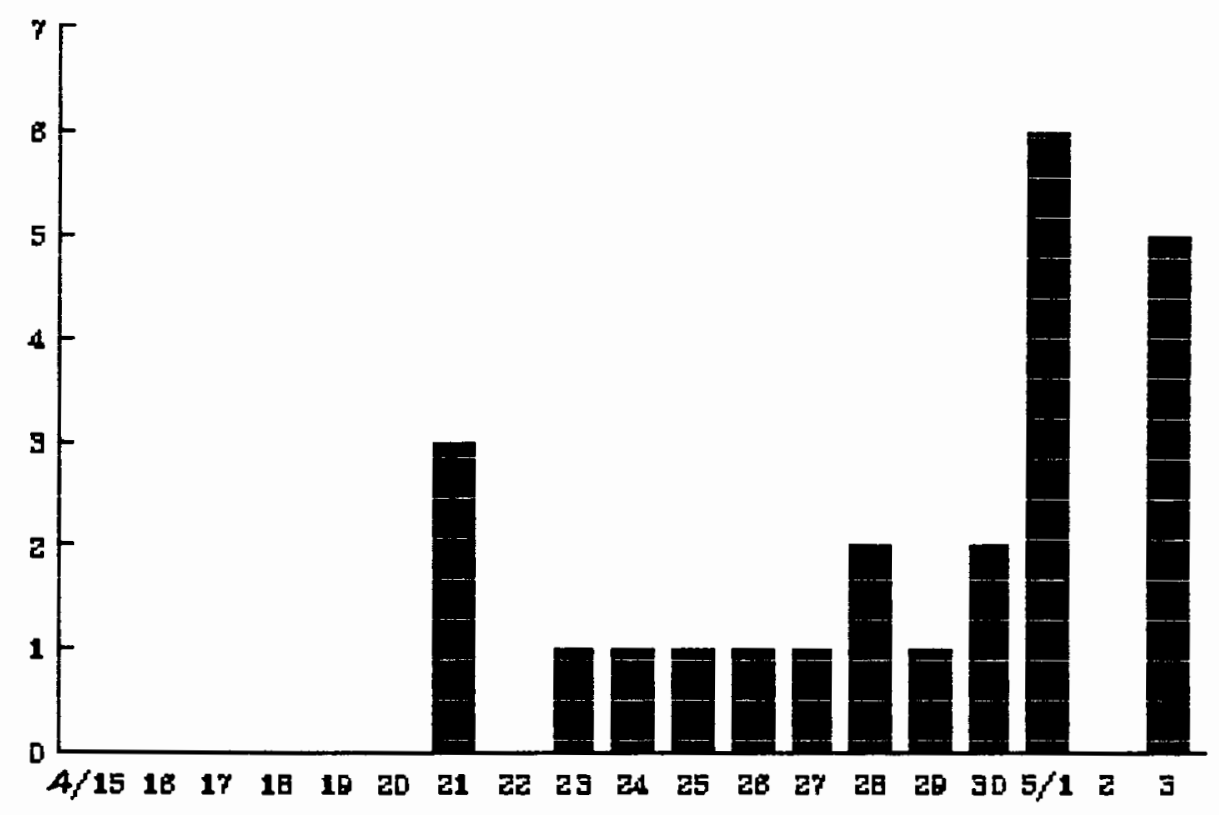

The vertical numerical unit is the number of articles in the People's Daily.

Figure 2 shows that in the first research period the People's Daily did not pay much attention to the prodemocracy movement, though the attention was increasing at the end of this period. In about two weeks, 24 articles regarding the movement were carried in the People's Daily, 19 on front pages and only 5 on inside pages. 
Although the People's Daily did not report the students' activities at the beginning of the movement, on April 23, 1989, the Science and Technology Daily, a state-controlled newspaper, published a factual account of the students' activities, and thus it broke with the government control on news media that had lasted for forty years in China. The newspaper carried large photographs of student demonstrations. Copies were quickly pasted up on bulletin boards in Beijing universities.

At the same time, the World Economic Herald in Shanghai carried several articles in memory of $\mathrm{Hu}$ in its April 24 issue. The articles praised Hu for rectifying the treatment of thousands of intellectuals who suffered during the Cultural Revolution, and criticized the Party for being responsible for removing Hu from his post in 1987. Qin Benli, the editor-in-chief, ignored the order of Jiang Zheming, the then Party chief in Shanghai, to replace the articles in memory of $\mathrm{Hu}$, instead, he left a blank space in the reprinted issue to show that something had been censored (Hsiao \& Yang, 1990).

The April 23 issue of the Science and Technology Daily and the Economic Herald incident encouraged the students to call for freedom of the press. The students hoped that with freedom of the press the media would help create a positive image for their movement. 
Figure 3

Attention to the movement

$$
(5 / 4 / 89--5 / 19 / 89)
$$

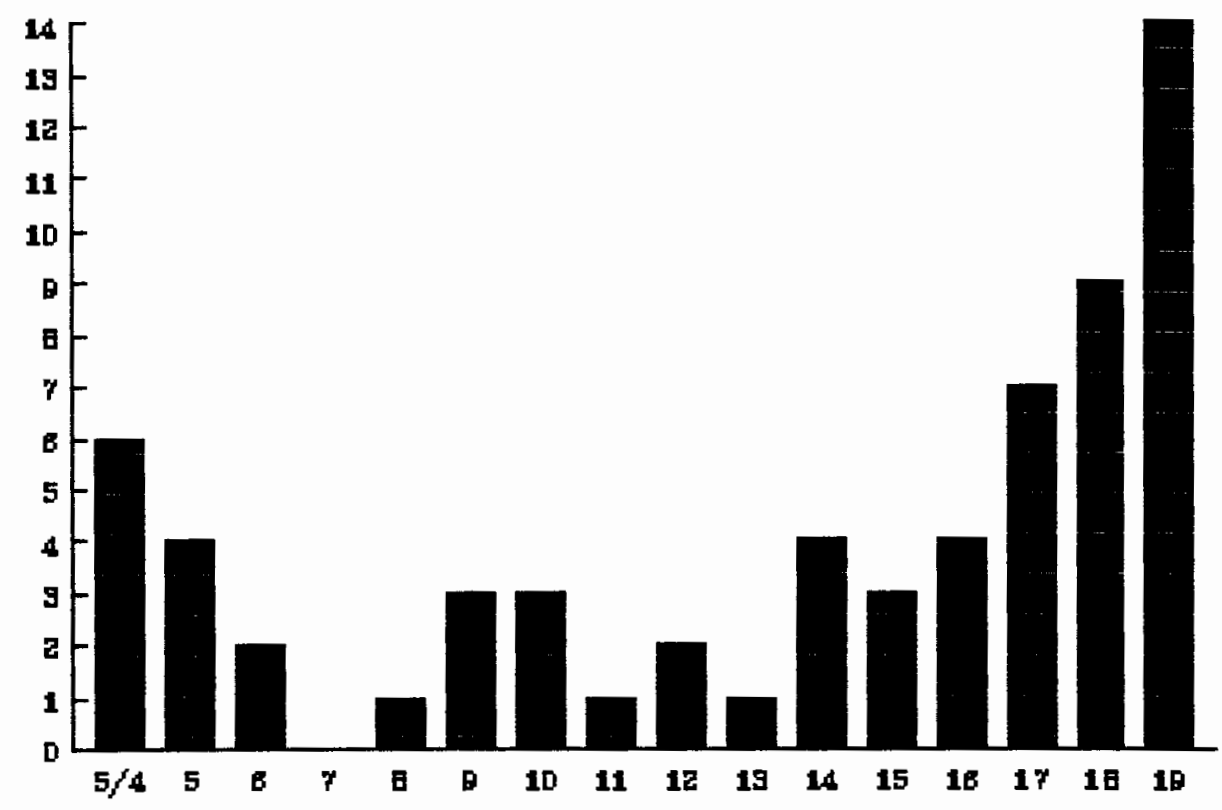

The vertical numerical unit is the number of articles in the People's Daily.

After the journalists joined the unprecedented demonstration on May 4, 1989, the news coverage of the movement in the People's Daily increased greatly, especially on May 17, 18, and 19. During this period, there were 39 related news articles on front pages and 24 on inside pages. on May 5th, the front page of the People's Daily, for the first time, carried two large photographs of the massive demonstrations held that day. At the same time, long, detailed, and sympathetic articles on the demonstrations and on the hunger strikes appeared in the People's Daily. "One Million From All Walks of Life Demonstrate In Support of 
Hunger-Striking students" was the main headline on May 18 in the People's Daily (People's Daily, May 18, 1989, p.1). "Save the students, Save the children," is another front page article supporting the movement. On May 18, the people's Daily printed a front page story about its own staff participating in the massive demonstration along with a large picture of its own members on the march. The article read "... over one thousand reporters and workers from our own paper took part in the demonstrations, with several renowned and respected writers and editors at the head of the line.... (People's Daily, May 18, 1989, p.1). As the People's Daily walked away from the Party line, other official newspapers, magazines, national T.V. and radios stations followed. For Example, China Daily, the China Youth Daily, Beijing Review, the Chinese Women's News, the Science and Technology Daily News, Radio Beijing, and the Central Broadcasting station covered the demonstrations. As Polumbaum (1990) put it, "The official newspapers, with the People's Daily at the vanguard, provided a virtual celebration of the demonstrations in sympathetic front-page stories and a plethora of photographs" (Polumbaum, 1990, p. 38). 
Figure 4

Attention to the movement

$$
(5 / 20 / 89-6 / 3 / 89)
$$

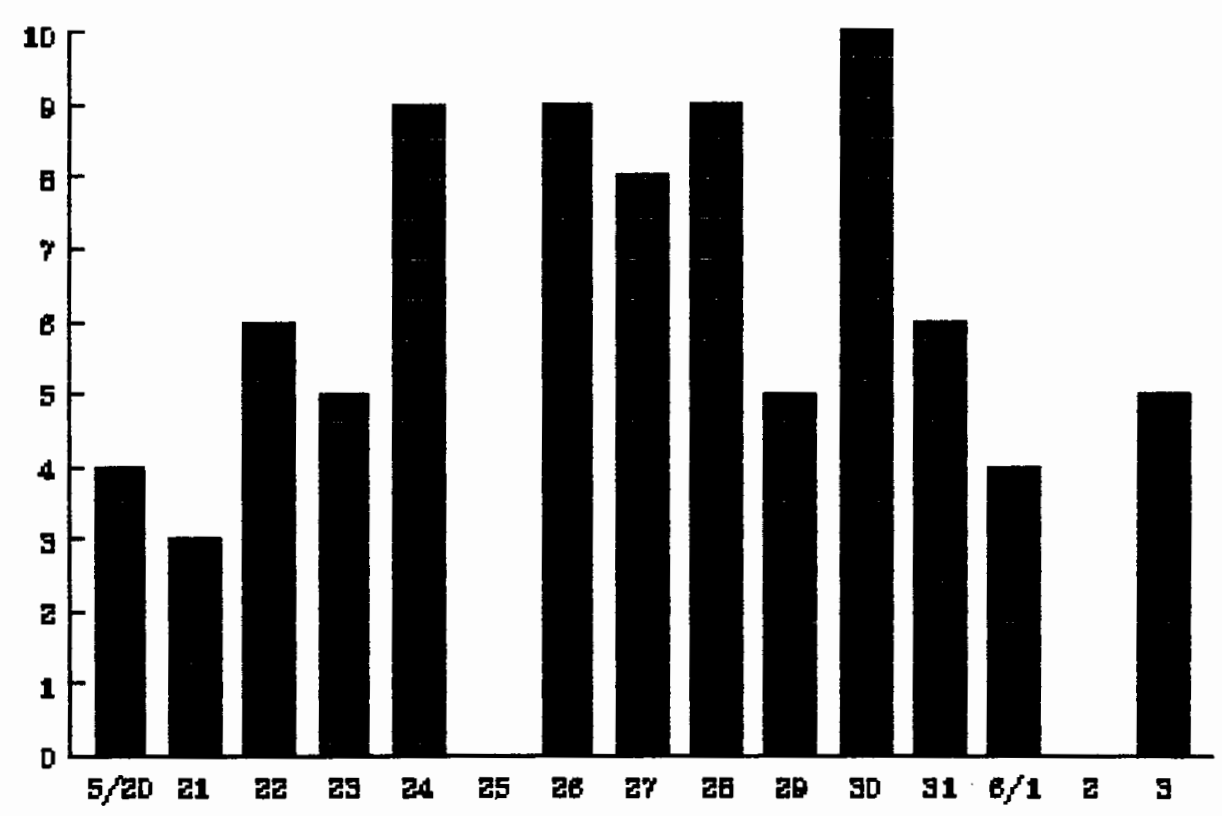

The vertical numerical unit is the number of articles in the People's Daily.

In the third research period (after the imposition of martial law in Beijing), the People's Daily increased its overall attention to the movement, though the tone of the news coverage towards the movement changed dramatically. 72 related news articles appeared on front pages, and 8 on inside pages. From May 23 on, the People's Daily began to publish a series of articles supporting the government and condeming the pro-democracy movement. 
Figure 5

Attention to the movement

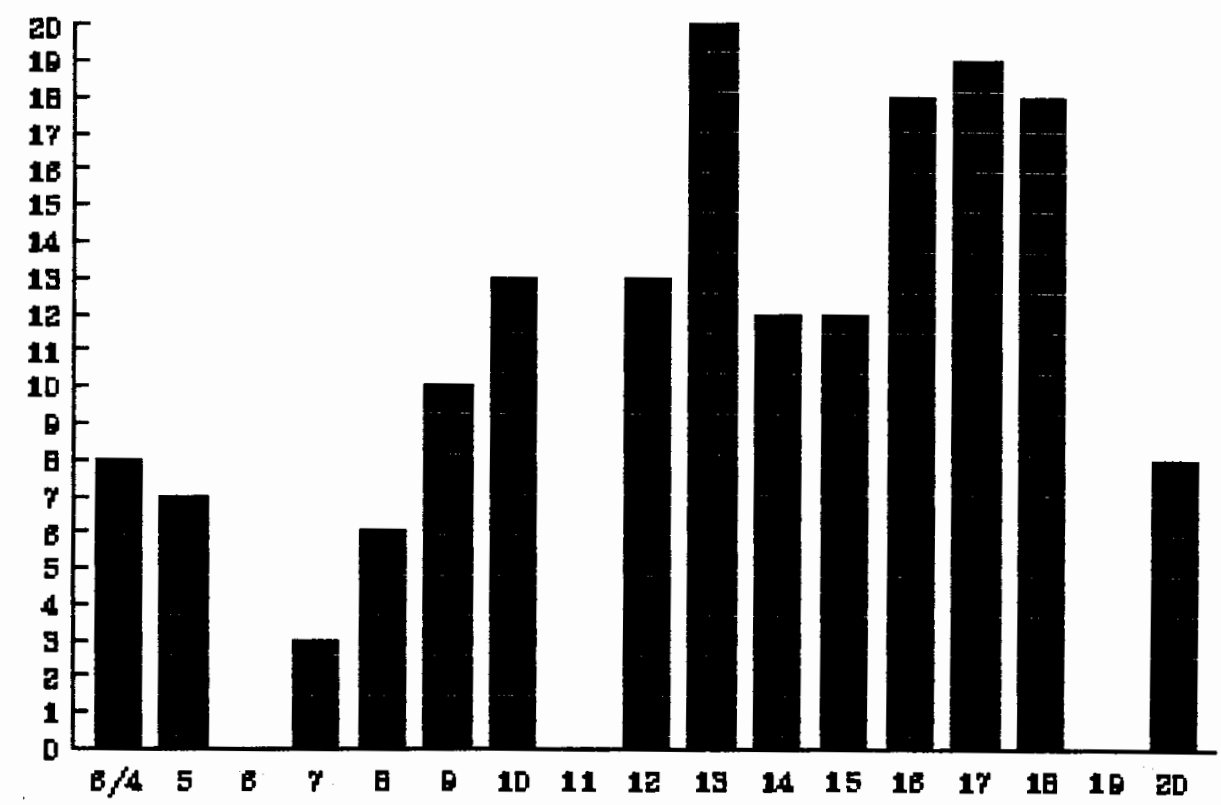

The vertical numerical unit is the number of articles in the People's Daily.

After the Chinese government used military force to crush the pro-democracy movement on June 4, 1989, the news coverage of the movement kept increasing, especially after June 9 when Deng Xiaopeng appeared on a national T.V. praising the martial law soldiers. At this time, the People's Daily repeatedly referred to the movement as a counterrevolutionary rebellion. 
TABLE I

SUMMARY OF ATTENTION TO THE MOVEMENT (4/15/89 -- 6/20/89)

\begin{tabular}{|c|c|c|c|c|}
\hline & $\begin{array}{c}\text { Front Page } \\
\text { Ar.\# }\end{array}$ & $\begin{array}{c}\text { Inside Page } \\
\text { Ar. \# }\end{array}$ & $\begin{array}{l}\text { Total } \\
\text { Ar.\# }\end{array}$ & $\begin{array}{l}\text { Total } \\
\text { ph. }\end{array}$ \\
\hline $4 / 15 / 89-5 / 3 / 89$ & 19 & 5 & 24 & 136 \\
\hline $5 / 4 / 89-5 / 19 / 89$ & 36 & 24 & 60 & 338 \\
\hline $5 / 20 / 89-6 / 3 / 89$ & 72 & 8 & 80 & 453 \\
\hline $6 / 4 / 89-6 / 20 / 89$ & 91 & 100 & 191 & 1089 \\
\hline
\end{tabular}

In summary, the attention that the People's Daily gave to the pro-democracy movement kept increasing from the first to the last research period. There was an overall increase both in front-page coverage and in inside-page coverage.

\section{TABLE II}

SYMBOLIC TERMS OF THE MOVEMENT (4/15/89 -- 5/3/89)

\begin{tabular}{|c|c|c|}
\hline Terms & Number & $\mathrm{Ph}$. \\
\hline counterrevolutionary* & 30 & 24 \\
\hline rioters * & 20 & 18 \\
\hline turmoilt & 29 & 21 \\
\hline a handful of peoplet+ & 18 & 14 \\
\hline
\end{tabular}

* This symbol includes anti-party, anti-socialist system, illegal. ** This symbol includes hooligans, trouble-makers, instigators. + This symbol includes political disturbance, rebellion, comparing the movement to the cultural Revolution.

++ This symbol includes very few people, a small number of people.

Table II shows that during the first research period, 
the People's Daily used only negative terms to describe the pro-democracy movement. No neutral or positive terms were found in the People's Daily. The most used negative terms in this period were "counterrevolutionary" (30) and "turmoil" (29). On April 26, 1989, the People's Daily published an editorial denouncing the student movement as a cause of "turmoil." This editorial set the negative tone of news coverage towards the movement until the end of the first research period. The editorial directly accused certain people of using the occasion of $\mathrm{Hu}^{\prime} \mathrm{s}$ death for creating chaos:

... a handful of people with ulterior motives made use of the students mourning of Comrade Hu Yaobang. They have spread all sorts of rumors to poison people's minds. They have resorted to big and small character posters to smear, scold, and attack our party and government leaders. They have wantonly violated the Constitution to advocate opposition to the Communist Party's leadership and the socialist system. They have formed illegal organizations and spread counterrevolutionary leaflets... (Mu \& Thompson, 1989, p. 27).

After the publication of the editorial of April 26, 1989, the People's Daily continued to use negative terms to refer to the movement. Reports of "hooligans" and "rioters" in different cities appeared in the newspaper. 
TABLE III

SYMBOLIC TERMS OF THE MOVEMENT (5/4/89-- 5/19/89)

\begin{tabular}{|c|c|c|}
\hline Terms & Number & $\mathrm{Ph}$. \\
\hline counterrevolutionary & 10 & 7 \\
\hline rioters & 0 & 0 \\
\hline turmoil & 11 & 8 \\
\hline a handful of people & 4 & 3 \\
\hline student movement* & 188 & 159 \\
\hline patriotic** & 214 & 194 \\
\hline
\end{tabular}

* This symbol includes student demonstrations, student protests. ** This symbol includes peaceful, legal, nonviolent, popular. Ph. stands for paragraphs.

As Table III shows, negative terms of the movement used by the People's Daily decreased greatly in the second research period. From May 4, 1989, neutral and positive terms began to appear in the People's Daily. The newspaper used neutral terms 188 times and positive terms 214 times. The journalists'participation in the demonstrations was a turning point for the movement. On May 4, reporters and editors of the People's Daily carried a banner which read, "Resolutely Oppose the April 26 Editorial!" The Guangming Daily, the Workers' Daily, the Peasants' Daily and the New China News Agency supported them. Their banners said "We want to tell the truth; Don't force us to lie. We want to speak but we can't" (Hsiao \& Yang, 1990, p. 121). The Central People's Broadcasting Station reporters carried a sign saying "CPBS News: Students Have Fasted For Three Days, 
From May 13 to 15" (Liu, 1989, p. 33). The journalists' support helped advance the movement, especially the appearance of the People's Daily staff in the demonstrations. As Liu (1989) stated:

The student movement reached its climax between May 14 and 20. Without those few days of "liberal" newspapers, there would have been no such climax for the movement. The communist party would not admit that the student movement was patriotic and democratic but the Party newspaper admitted it (p.28).

Support for the movement was also seen in the People's Daily on May 19, 1989. One article claimed: "The current student movement was a patriotic and democratic movement. It reflected the wills of the ordinary people and obtained more and more sympathy and support from people of all walks of life" (People's Daily, May 19, 1989, p. 2).

\section{TABLE IV}

SYMBOLIC TERMS OF THE MOVEMENT (5/20/89 -- 6/3/89)

\begin{tabular}{|c|c|c|}
\hline Terms & Number & $\mathrm{Ph}$. \\
\hline counterrevolutionary & 111 & 85 \\
\hline rioters & 15 & 10 \\
\hline turmoil & 241 & 181 \\
\hline a handful of people & 101 & 80 \\
\hline student movement & 30 & 26 \\
\hline patriotic & 60 & 46 \\
\hline
\end{tabular}

As Table IV shows, in the third research period, the negative terms of the movement increased dramatically, and 
neutral and positive terms decreased greatly. The most used negative terms were the ones which appeared in the first period, "turmoil" (241) and "counterrevolutionary" (111), though the frequency of usage increased more than ten times. After the imposition of martial law (May 20, 1989), the Party tried to resume tight control over the media, but for the first few days, negative, neutral, and positive articles appeared in the People's Daily (see People's Daily, May 21, $22,23,1989)$. Only negative terms appeared when Li Peng had reorganized the propaganda department, and the reform faction of the Party lost power. A "work team" of plainclothes soldiers entered the newspaper compound (Faison, 1989). As a result, a black box that appeared on front pages, to remind readers how many days the martial law had been in effect, disappeared. Photographs of demonstrators stopped appearing in any form. By June 3, there were no favorable reports on the movement.

On May 20, the People's Daily published Li Peng's speech at a meeting attended by top Party, government, and military leaders. In the speech, Li Peng declared:

It has been more and more clear that a tiny minority of people want to create turmoil and so to reach their political goal which is to negate the leadership of the chinese communist Party and the socialist system. They stir up trouble everywhere, establish secret ties, set up illegal organizations, conduct counterrevolutionary activities (Mu \& Thompson, 1989, p. 178).

Li Peng's speech set the negative tone of the news 
coverage of the People's Daily in this research period. In the following weeks, the People's Daily carried a string of letters of support for the government and condemnation for the movement from many military leaders and provincial Party committees. For example, on May 22, 1989, the People's Daily devoted most of its front and second pages to letters of support from 7 provincial government committees. One letter from Fujian province stated:

Everybody realized the importance and timeliness of comrade Li Peng's speech. The speech correctly and factually analyzed the current situation, emphasized the seriousness of this struggle, put forward the concrete suggestions of resolutely quelling the turmoil and quickly restoring order. The speech provided guidance to maintain stability and unity, the reform and open policy and socialist modernization. The current turmoil stemmed from a handful of people aimed in essence to negate the leadership of the communist Party and the socialist system (People's Daily, May 22, p. 2).

\section{TABLE V}

SYMBOLIC TERMS OF THE MOVEMENT $(6 / 4 / 89--6 / 20 / 89)$

\begin{tabular}{|c|c|c|}
\hline Terms & Number & Ph. \\
\hline counterrevolutionary & 685 & 378 \\
\hline rioters & 232 & 167 \\
\hline turmoil & 413 & 269 \\
\hline a handful of people & 211 & 102 \\
\hline
\end{tabular}

In the last research period (after the military suppression), the People's Daily took the most negative attitude towards the movement and devoted most of its 
attention to making increasing references to the movement as a counterrevolutionary rebellion (see Table V). The negative term "counterrevolutionary" increased from 111 times in the third period to 685 in the last period, the term "rioters" increased from 15 to 232 times, and the term "turmoil" increased from 241 to 413 times. The phrase "a handful of people" increased from 101 to 211 times. Also neutral and positive terms disappeared completely in this research period.

At this time, the press once again was used as the Party's tool to convince people of its version of the events in Beijing. It tried to persuade people that military action had been necessary to quell a "counterrevolutionary rebellion." Thus, the military suppression of the movement was justified. In a speech, the Mayor of Beijing, chen Xitong stated:

A handful of people in Beijing stirred up a serious counterrevolutionary rebeliion. In order to protect the socialist system, the people's government, the safety of people's lives, the martial law soldiers quelled the counterrevolutionary rebellion" (People's Daily, June 5, 1989, p. 1).

In another detailed account of the "real story" of the Tiananmen incident in the People's Daily on June 10, 1989, the government stated that

.... By 5:30 A.M., the clearing operation of the Square, which lasted half an hour, was complete. During the whole process....no one died. This shows that rumors of 'rivers of blood' running in Tiananmen Square were completely unfounded. There had been civilian deaths, but those came only after vicious rioters had beaten, burned and killed the 
People's liberation soldiers (People's Daily, June 10, 1989).

TABLE VI

SUMMARY OF SYMBOLIC TERMS OF THE MOVEMENT

\begin{tabular}{|c|c|c|c|c|c|}
\hline & $-5 / 3$ & $5 / 4-5 / 19$ & $5 / 20-6 / 3$ & $6 / 4-6 / 20$ & $\begin{array}{r}\text { Total } \\
\mathrm{Ph} .\end{array}$ \\
\hline $\begin{array}{l}\text { counter- } \\
\text { revolutionary }\end{array}$ & 30 & 10 & 111 & 685 & 498 \\
\hline rioters & 20 & 0 & 15 & 232 & 201 \\
\hline turmoil & 29 & 11 & 241 & 413 & 483 \\
\hline handful & 18 & 4 & 101 & 211 & 199 \\
\hline $\begin{array}{l}\text { student } \\
\text { movement }\end{array}$ & 0 & 188 & 30 & 0 & 105 \\
\hline patriotic & 0 & 214 & 60 & 0 & 139 \\
\hline
\end{tabular}

In summary, most news entries in the first and last research periods were negative. Only in the second period did neutral and positive news entries appear. In the last research period, negative terms increased to their highest point.

Correspondence Between the Movement and News Coverage

Information generated from the research findings showed that there was a close correspondence between changes in the pro-democracy movement and changes in the press coverage of the movement. The following is a detailed discussion of the relationship between the movement and the press coverage of it in the four research periods. 
Figure 6

Correspondence between the movement and attention to the movement $(4 / 15 / 89-5 / 3 / 89)$.

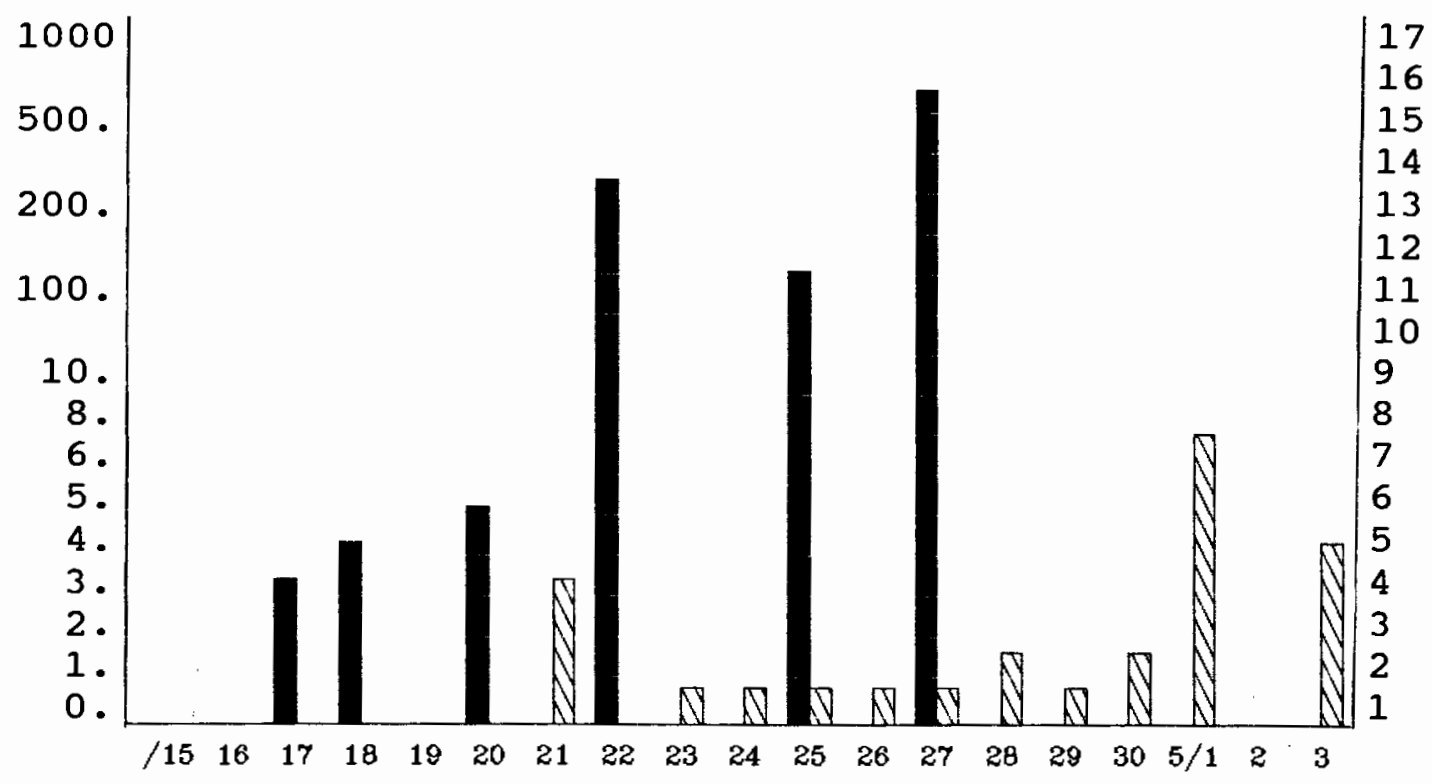

demonstrations MIV attention

The vertical numerical unit on the left is in thousands, displayed as unequal intervals for summary convenience. It stands for the number of demonstrators. The vertical numerical unit on the right is the number of articles in the People's Daily.

In the first research period, as Figure 6 shows, there was no close correspondence between the movement and the press coverage of the movement. While the student demonstrations were on the rise, the People's Daily downplayed the movement, as it did with previous student movements in 1986 and 1987 (Lee, 1990). The newspaper started to cover the student activities negatively on April 21, 1989, and it paid minimum attention to the student 
movement until April 27, 1989. From April 28 to May 3, when there were no demonstrations, the People's Daily increased its coverage of the movement. At that time, the students were preparing a dialogue with the government which was scheduled for April 29, 1989.

\section{Figure 7}

Correspondence between the movement and the People's Daily's attitude towards it (4/15/89-5/3/89).

Negative terms towards the movement

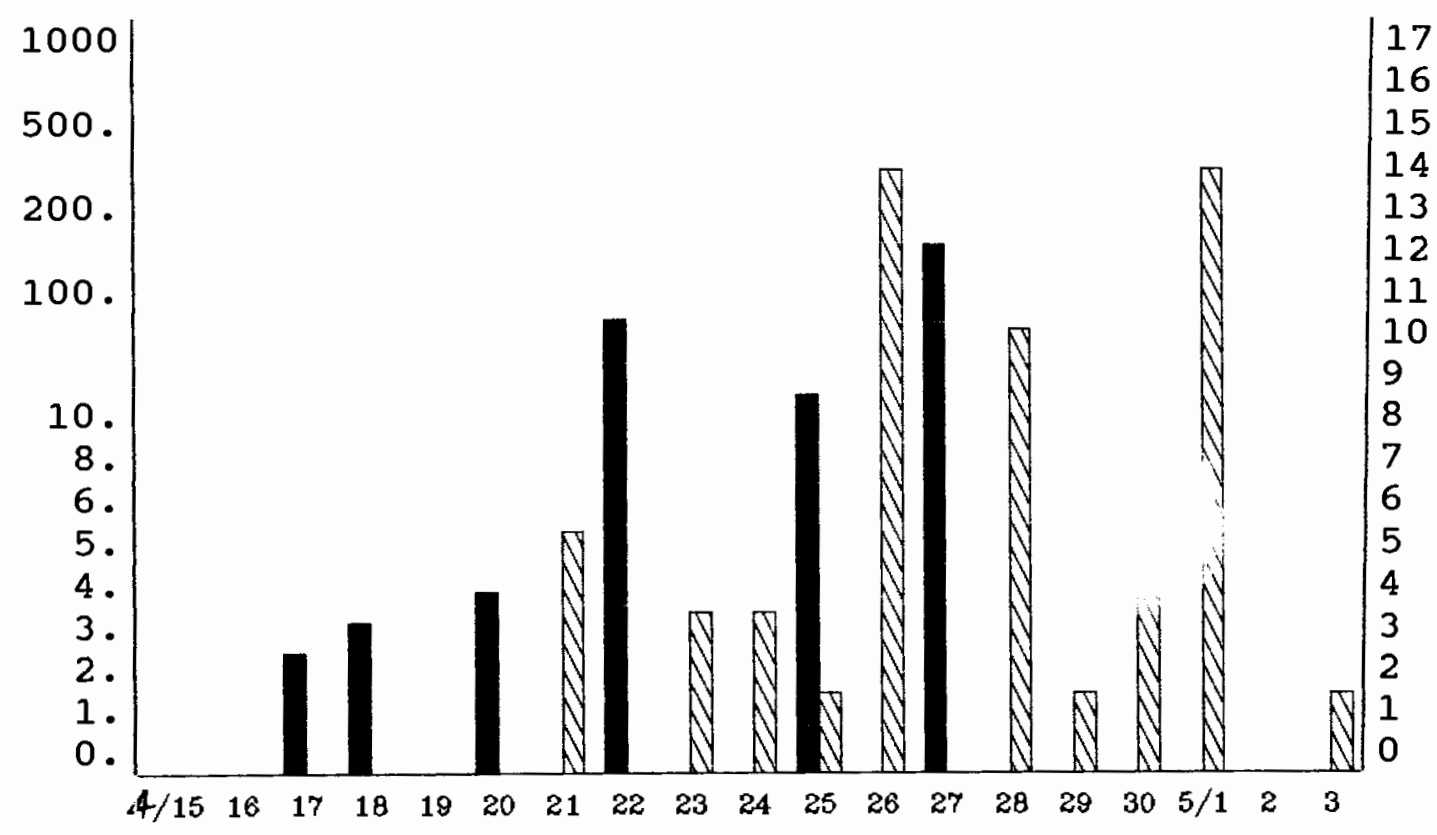

Demonstrations $\$ 10$ negative terms

The vertical numerical unit on the left is in thousands, displayed as unequal intervals for summary convenience. It stands for the number of demonstrators. The vertical numerical unit on the right is the number of times that the People's Daily used negative terms to describe the movement.

As Figure 7 shows, the People's Daily started to carry 
negative terms on April 21, 1989. The use of negative terms on April 26 was at its peak. The main reason for this sharp increase of negative terms was directly related to the April 26 editorial of the newspaper. Towards the end of April, the students ceased their demonstrations to prepare for their dialogue with the government, then the People's Daily decreased its negative terms. On May 1, the newspaper once again increased its negative terms, but two days later, dropped to its minimum.

Figure 8

Correspondence between the movement and the People's Daily's attitude towards it (4/15/89-5/3/89)

The phrase "a handful of people"

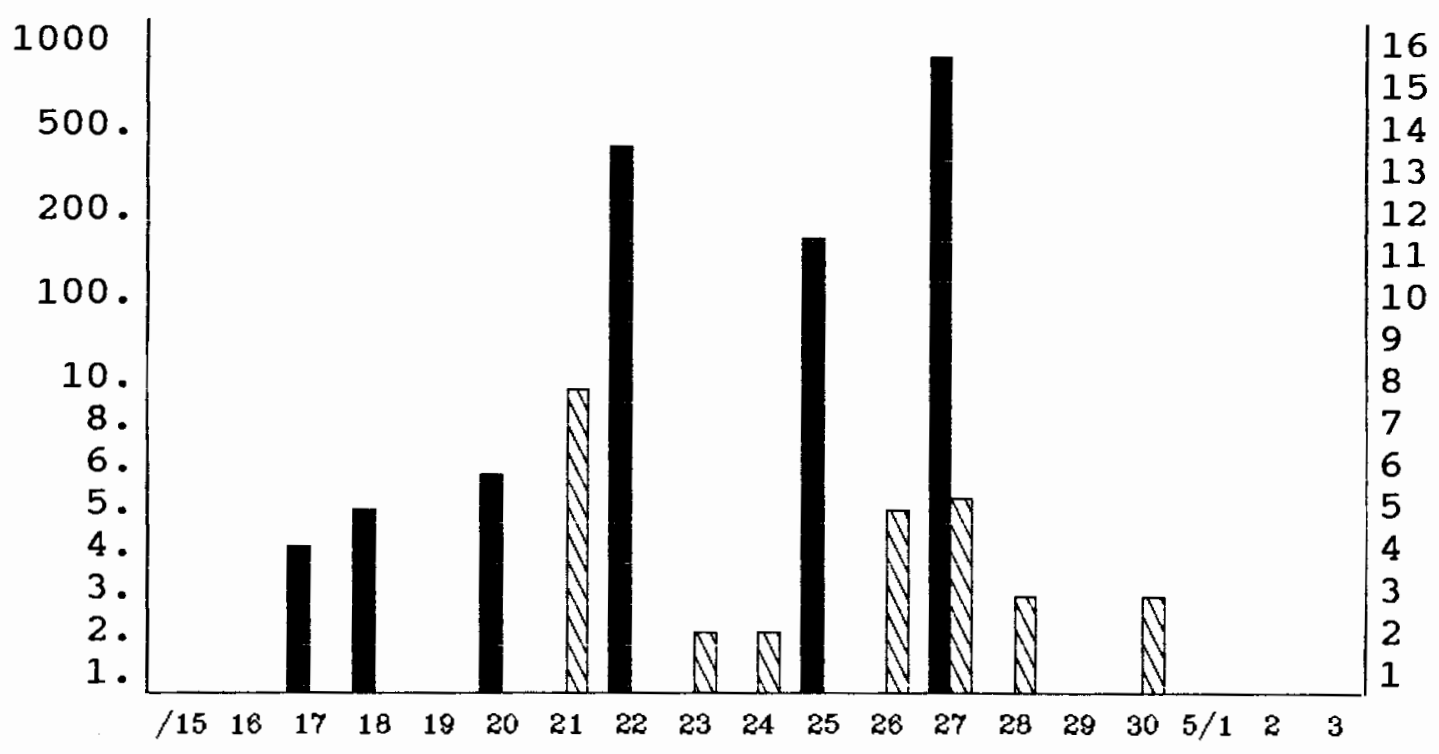

demonstrations SIVIV hendful of people

The vertical numerical unit on the left is in thousands, displayed as unequal intervals for summary convenience. It stands for the number of demonstrators. 
The vertical numerical unit on the right is the number of times that the People's Daily used "a handful of people" to describe the movement.

As shown in Figure 8, on April 21, 1989, the People's Daily repeatedly used "a handful of people" to refer to the movement. When half a million took to the streets on April 27, 1989, the People Daily once again used "a handful of people" to refer to the massive demonstration. In addition, despite the fact that there were no demonstrations from April 28 to 30,1989 , the People's Daily still used the phrase to refer to the pro-democracy movement.

\section{Figure 9}

Correspondence between the movement and attention to the movement $(5 / 4 / 89--5 / 19 / 89)$.

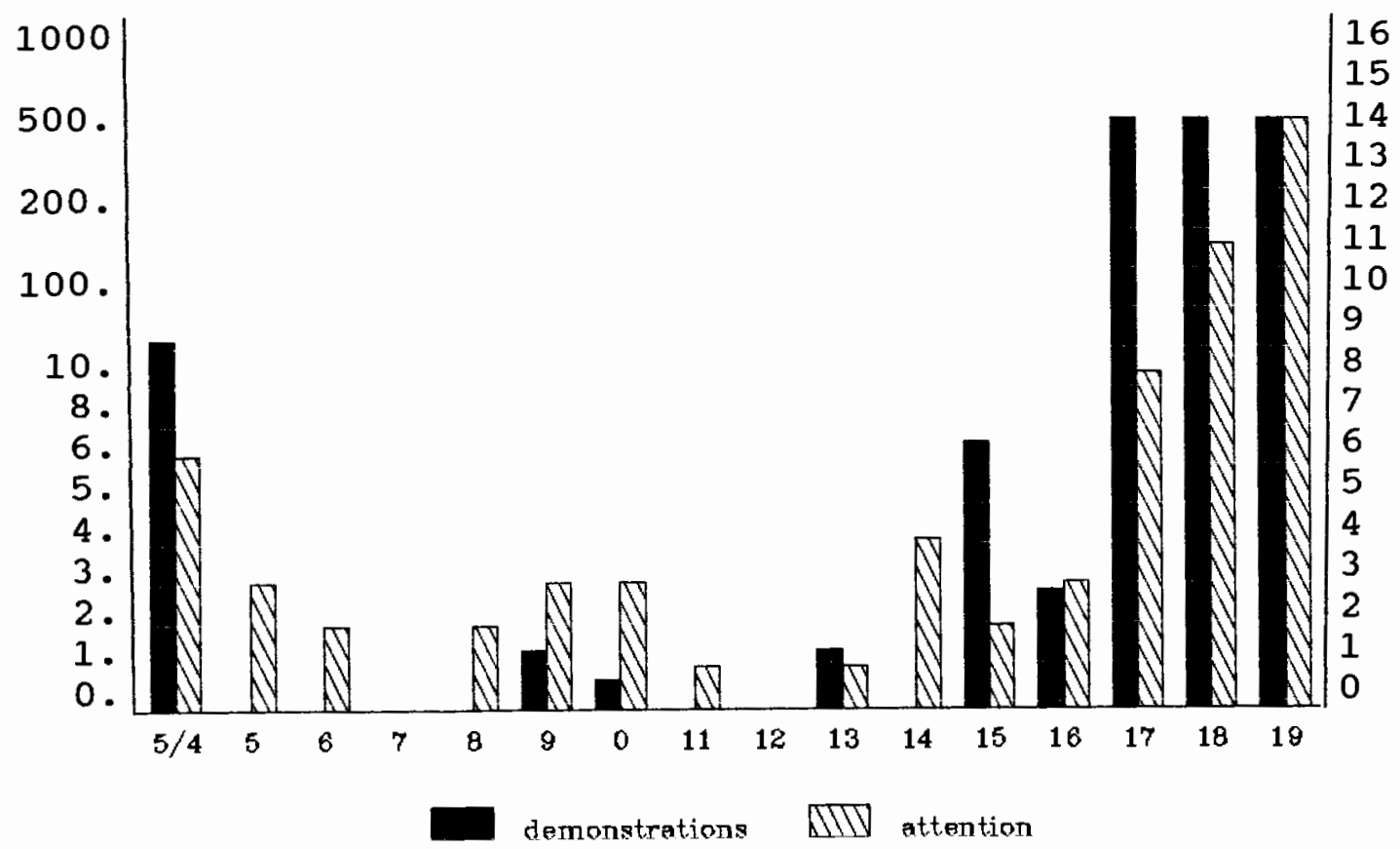

The vertical numerical unit on the left is in thousands, displayed as unequal intervals for summary convenience. It stands for the number of demonstrators.

The vertical numerical unit on the right is the number 
of articles in the People's Daily.

In the second research period, as Figure 9 shows, there was a close correspondence between the pro-democracy movement and the press coverage. The movement attracted worldwide attention for four main reasons: 1) the students gained support from people of almost all professions; 2) the students occupied Tiananmen Square, the symbolic center of the capital; 3 ) the students began hunger strike in Tiananmen Square on May 12, 1989; 4) the summit meeting between Gorbachev and Deng Xiaoping in Beijing in May 1989 brought international news reporters to Beijing.

After the massive demonstration on May 4, 1989, the demonstrations decreased, and so did the news coverage of the movement. Compared with the first research period, one obvious change in the movement is that the students no longer acted alone; they were joined by journalists, workers, police officers, government officials, and citizens in Beijing. From May 16, 1989, the movement took a sharp rise, and so did the coverage of the movement. For three days in a row, more than one million people demonstrated to show their support for the movement, and for the first time, the official news media, headed by the People's Daily, widely covered the movement. With large photos and detailed descriptions of the movement in the People's Daily, it seemed for a few days in May, 1989, the Chinese news media was free of Party control, but things changed dramatically after the government declared 
martial law in Beijing on May 20, 1989.

During this period, negative terms appeared only on May 4, 1989, when 100,000 people took to the streets to mark the 70th anniversary of the May Fourth Movement. On that day the People's Daily used negative terms 21 times. As the movement developed, negative terms disappeared in this period.

\section{Figure 10}

Correspondence between the movement and the People's Daily's attitude towards it (5/4/89-5/19/89)

Neutral terms towards the movement

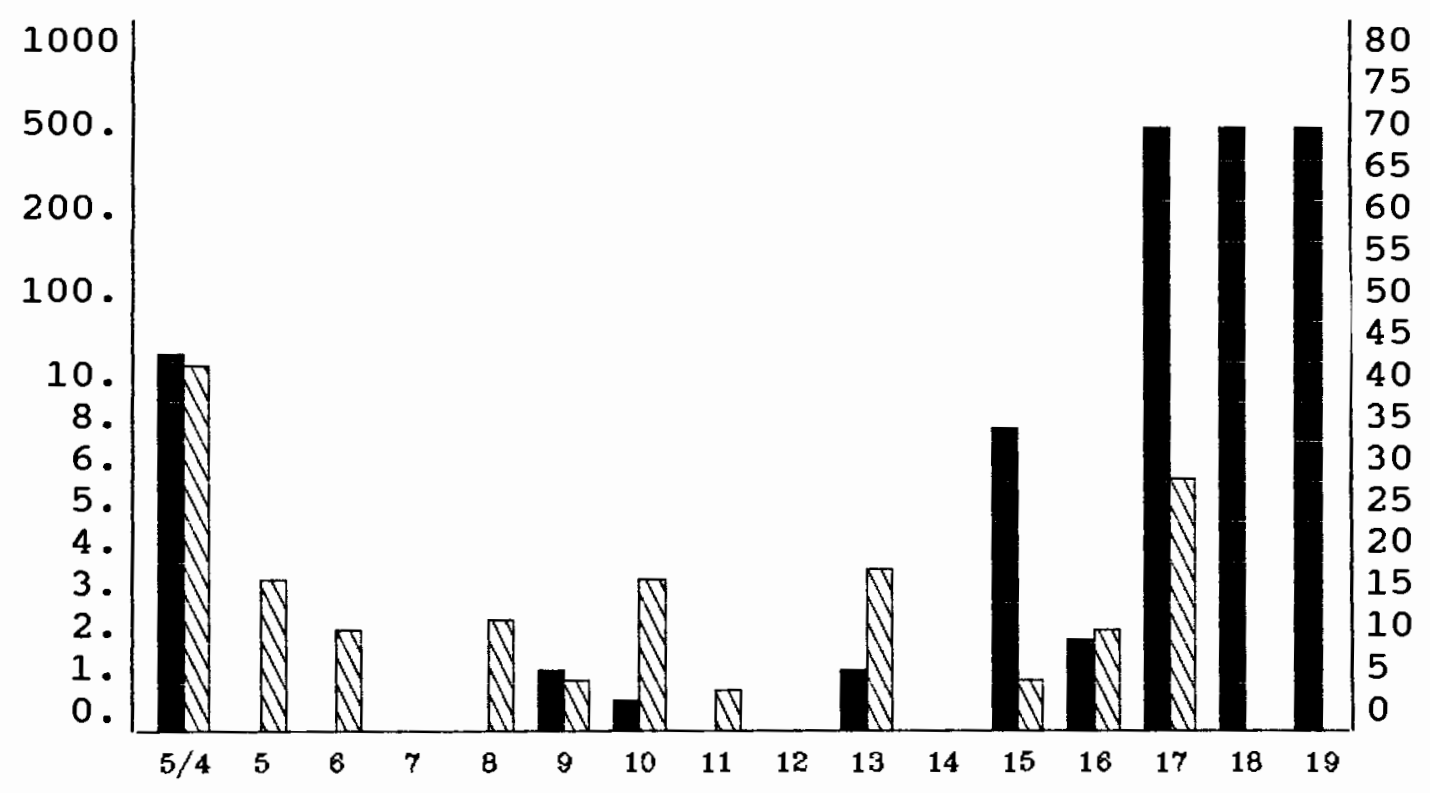

demonstrations AIII neutral terms

The vertical numerical unit on the left is in thousands, displayed as unequal intervals for summary convenience. It stands for the number of demonstrators. The vertical numerical unit on the right is the number of times that the People's Daily used neutral terms to describe the movement.

As Figure 10 shows, the People's Daily began to cover the movement in neutral terms from May 4, 1989. There was a 
slight decrease in the use of neutral terms from May 5 to May 12, 1989. During this time, the students were getting ready for the hunger strike. On May 13, 1989, neutral terms increased slightly because of the 1,000 hunger striking students on May 12, 1989. When the number of hunger striking students reached 3,000 four days later, neutral terms increased again, and they continued to increase until May 17, 1989, when the movement reached its climax.

Figure 11

Correspondence between the movement and the people's Daily's attitude towards it (5/4/89-5/19/89)

Positive terms towards the movement

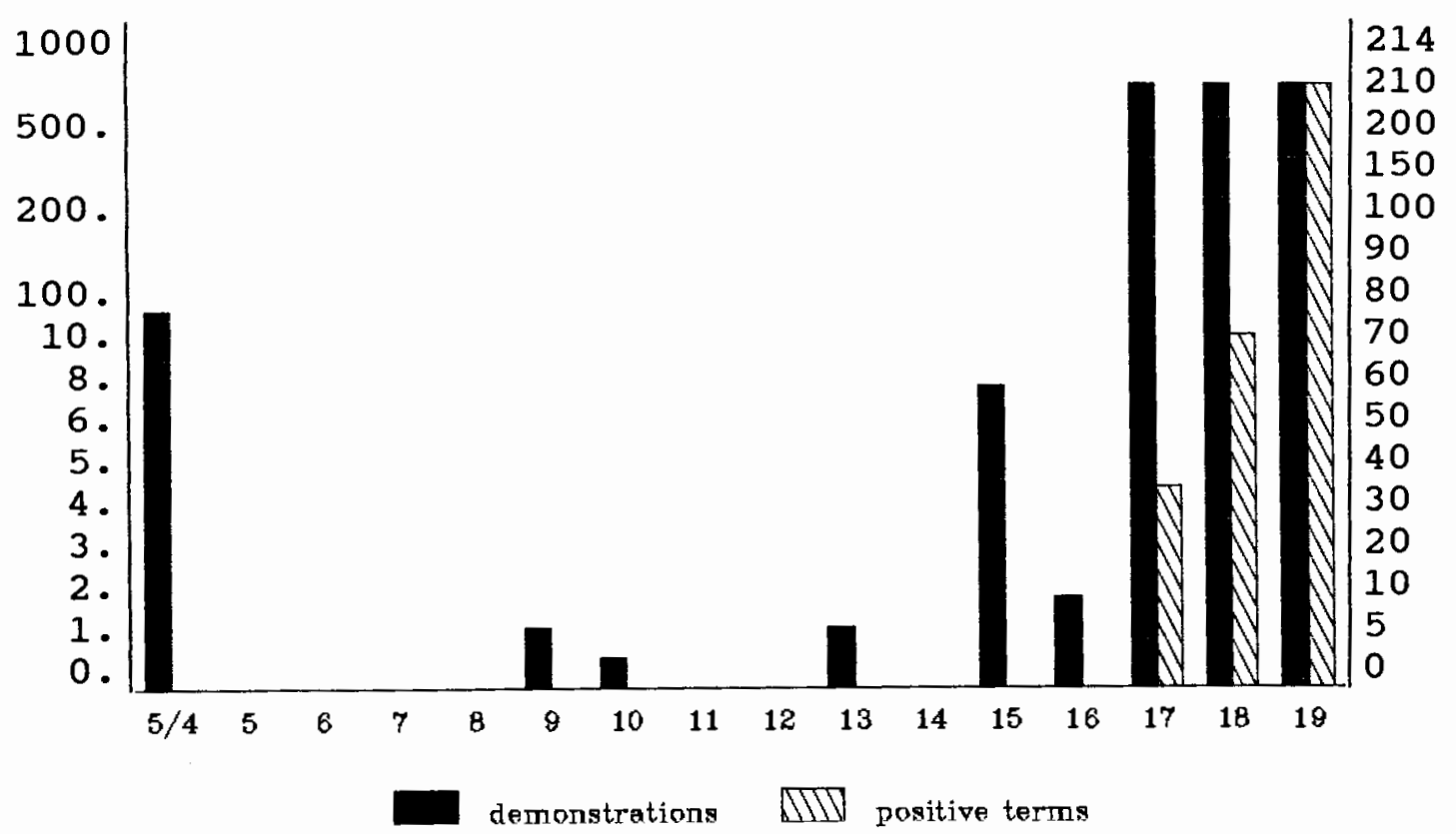

The vertical numerical unit on the left is in thousands, displayed as unequal intervals for summary convenience. It stands for the number of demonstrators. The vertical numerical unit on the right is the number of times that the People's Daily used positive terms to describe the movement. 
As Figure 11 shows, positive terms of the movement began to appear in the People's Daily at the end of the second research period (May 17, 18, 19, 1989), when three massive demonstrations took place. During these three days, the People's Daily kept increasing positive terms from 32 to 214 times. As Rosenthal (1989) said:

The fact that there was a time in May, 1989 when the government of China was overthrown as the real controlling authority will become part of China's history and is certain to affect China's future (Rosenthal, 1989, A.29).

Figure 12

Correspondence between the movement and attention to the movement $(5 / 20 / 89--6 / 3 / 89)$.

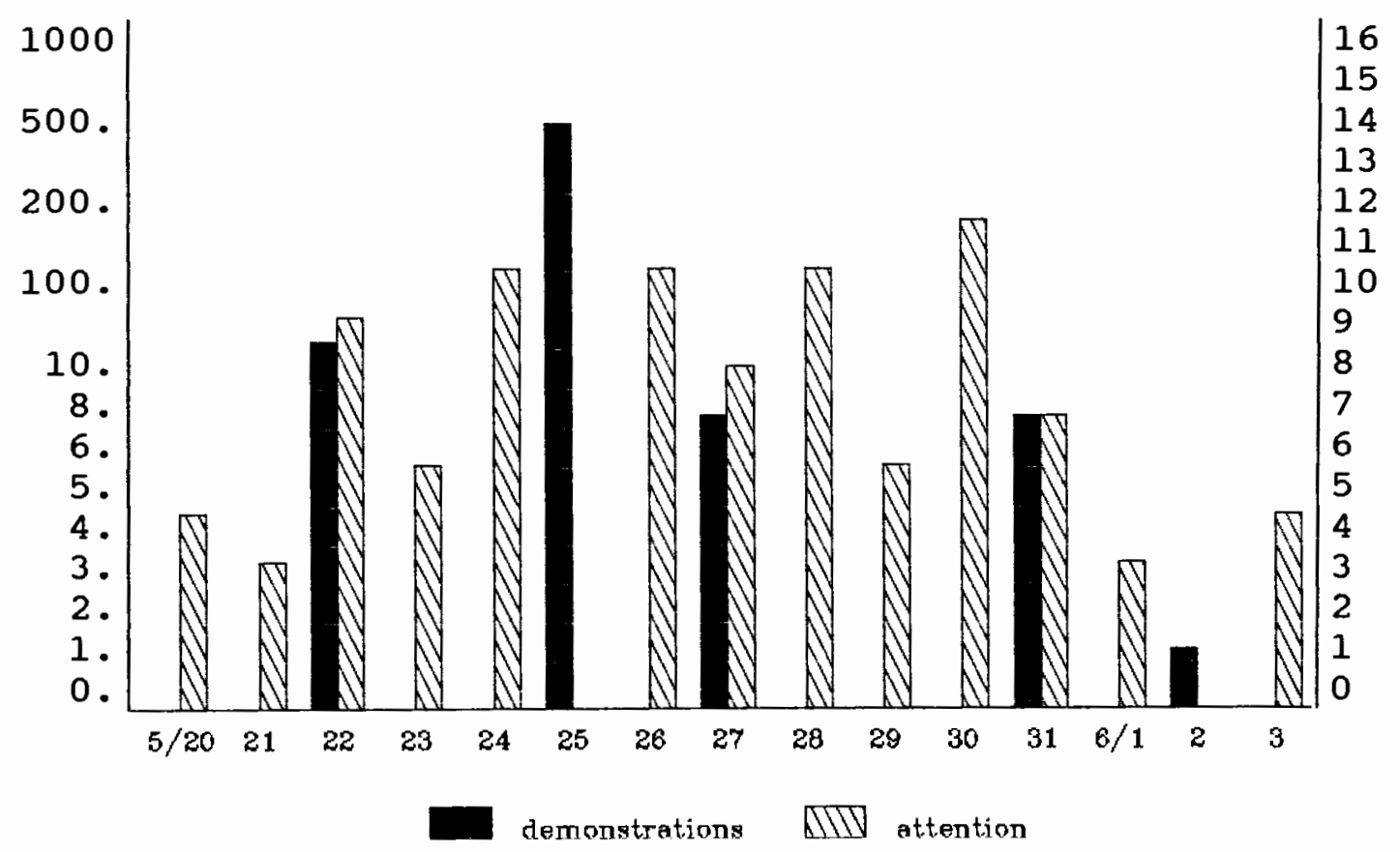

The vertical numerical unit on the left is in thousands, displayed as unequal intervals for summary convenience. It is the number of demonstrators.

The vertical numerical unit on the right is the number of articles in the People's Daily. 
As Figure 12 shows, in the third research period, the People's Daily continued to carry a large number of articles on the movement. As the movement rose, news coverage increased as well. However, news coverage decreased rapidly when martial law was declared. When 10,000 people demonstrated in protest of martial law on May 22, 1989, news coverage increased again. While people were out blocking troops from entering Beijing, news coverage decreased slightly. When one million people took to the streets to protest martial law on May 25, 1989, news coverage increased again. Towards the end of May into early June, there was a gradual decrease of news coverage of the movement.

Figure 13

Correspondence between the movement and the People's Daily's attitude towards it (5/20/89-6/3/89)

$$
\text { Negative terms towards the movement }
$$

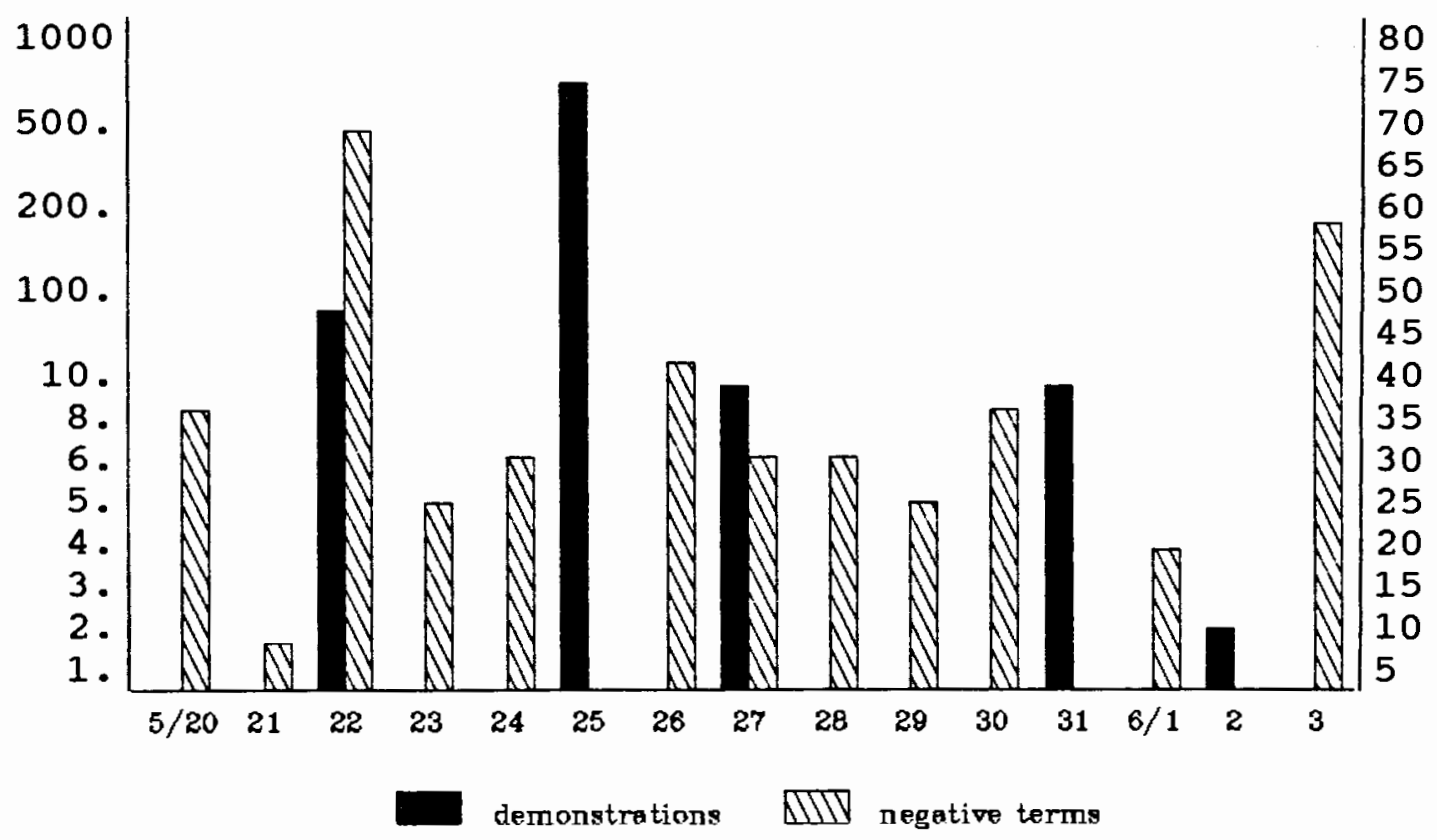

The vertical numerical unit on the left is in thousands, 
displayed as unequal intervals for summary convenience. It is the number of demonstrators.

The vertical numerical unit on the right is the number of times that the People's Daily used negative terms to describe the movement.

As Figure 13 illustrates, there was a deviation between trends in the movement and the press coverage of it in the third research period. When 10,000 people marched on May 22 to protest martial law, negative terms in the People's Daily increased, but then decreased when one million people demonstrated three days later. However, on June 3, 1989, before the military suppression of the movement, negative terms increased sharply.

Figure 14

Correspondence between the movement and the People's Daily's attitude towards it 5/20/89--6/3/89)

The phrase "a handful of people"

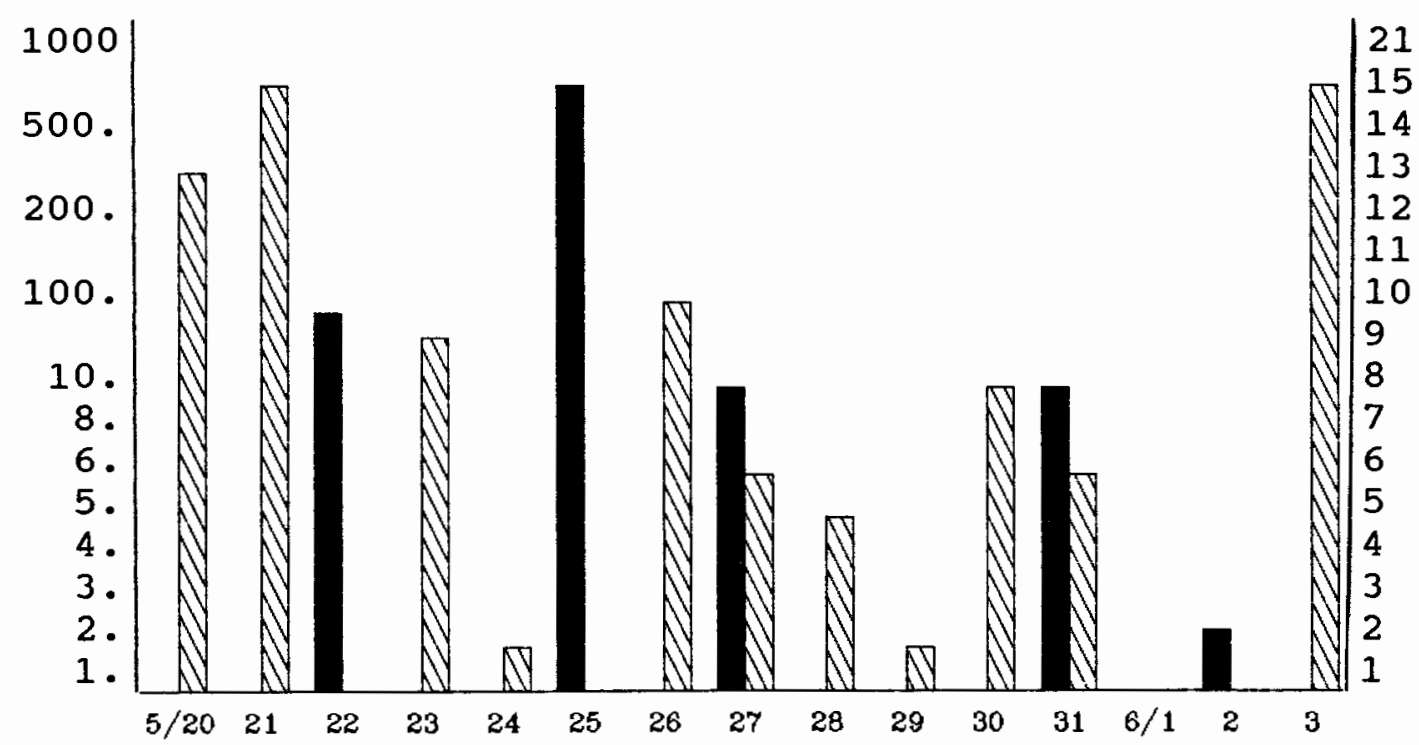

demonstrations MIIV a handful of people

The vertical numerical unit on the left is in thousands, displayed as unequal intervals for summary convenience. 
It is the number of demonstrators.

The vertical numerical unit on the right is the number of times that the People's Daily used "a handful of people" to describe the movement.

Throughout the third research period, the People's Daily frequently used "a handful of people" to deemphasize the movement. After one million people took to the streets on May 25, 1989, the next day, the People's Daily repeatedly used "a handful of people" to refer to the massive demonstration. This phrase was found in the People's Daily on a daily basis throughout this period.

Figure 15

Correspondence between the movement and the People's Daily's attitude towards it (5/20/89-6/3/89)

Neutral terms towards the movement

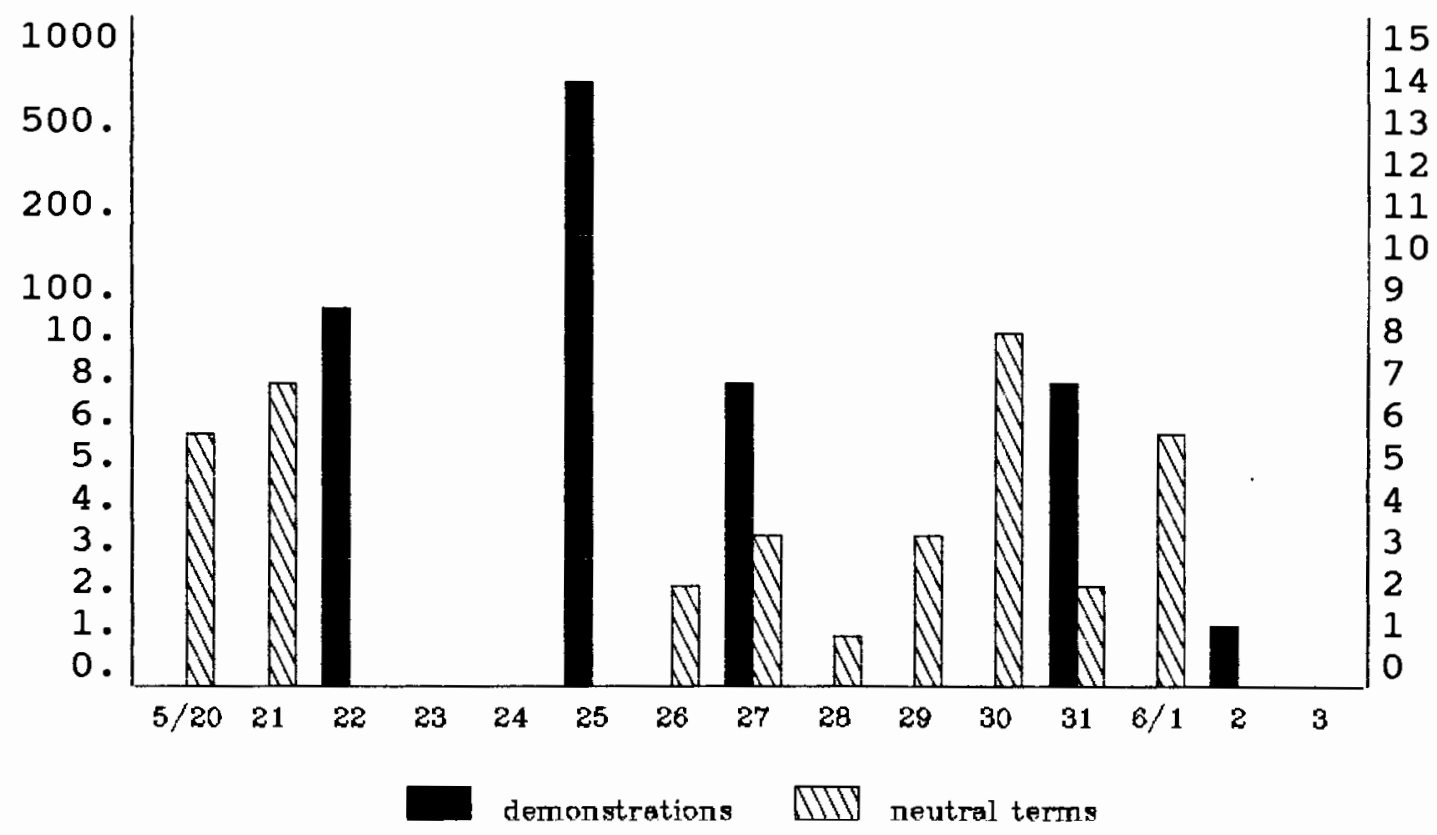

The vertical numerical unit on the left is in thousands, displayed as unequal intervals for summary convenience. It is the number of demonstrators.

The vertical numerical unit on the right is the number of times that the People's Daily used neutral terms to describe the movement. 
As figure 15 shows, the People's Daily used neutral terms steadily in the third research period, when the number of demonstrators and the frequency of demonstrations decreased. One important finding in this research period is the fact that shortly before the Chinese government used military force to clear Tiananmen Square, neutral terms disappeared completely, while negative terms and the phrase "a handful of people" increased sharply. This can be interpreted as a sign of the Party's renewed tight control over the news media.

Figure 16

Correspondence between the movement and the People's Daily's attitude towards it (5/20/89-6/3/89)

Positive terms towards the movement

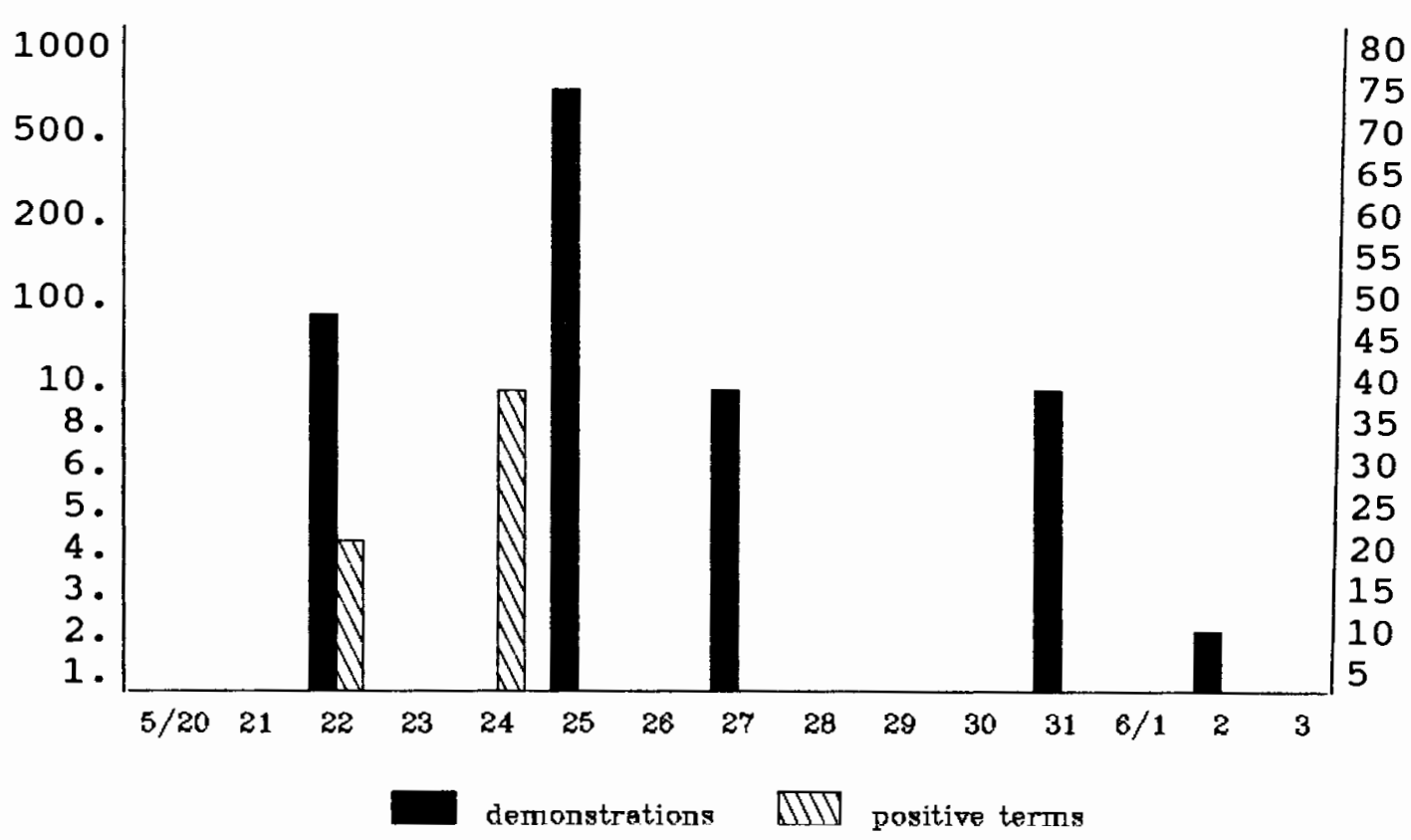

The vertical numerical unit on the left is in thousands, displayed as unequal intervals for summary convenience. It is the number of demonstrators.

The vertical numerical unit on the right is the number 
of times that the People's Dailv used positive terms to describe the movement.

As shown in Figure 16, the use of positive terms went up along with the rise of demonstrations before May 25, 1989. After May 25, 1989, the People's Daily used no positive terms. Instead, the newspaper steadily used negative and neutral terms, as shown in Figures 13 and 15.

Because there were no demonstrations after the government quelled the movement on June 4, 1989, there is no correspondence between the changes in the movement and in the press coverage of the movement in the last research period. Based on the above research findings, conclusions, limitations, and implications for future research are presented in Chapter Five of this study. 


\section{Chapter V}

\section{DISCUSSION AND CONCLUSION}

The purpose of this study is to examine the role of the Chinese news media in the 1989 Chinese pro-democracy movement. This research focuses on three aspects: 1) the development of the pro-democracy movement; 2 ) the changes in the press coverage of the movement; 3 ) the corresponding changes between the movement and the press coverage of it.

\section{SUMMARY OF THE RESEARCH FINDINGS}

\section{The Pro-democracy Movement}

The 1989 Chinese pro-democracy movement lasted about six weeks, from April 15, 1989 to June 4, 1989. The highlights of the pro-democracy movement can be examined according to the development of the movement.

The beginning of the movement was marked by the student demonstrations on April 17, 1989, after the death of former Party chief Hu Yaobang on April 15, 1989. The students petitioned to have $\mathrm{Hu}$ 's reputation restored, and they called for freedom of the press, more funds for education, and an end to official corruption. Getting no response from the government, the students boycotted classes and sat in at Tiananmen Square.

On April 26, 1989, the People's Daily published an 
editorial denouncing the student movement. The following day, half a million people, including students, workers, and citizens in Beijing, marched in the streets to protest what they saw as the official news media's distortion of the movement. In mid-May $1989,3,000$ hunger strikers were the center of attention, and aroused sympathy and understanding from people of different strata of society. This occupation of Tiananmen square became the center of media focus.

Another highlight of the movement was from May 16 to May 19, 1989. During these three days, one million people demonstrated in protest of the government's refusal to discuss the students' demands. After martial law was imposed on May 20, 1989, two days later, 10,000 intellectuals held a demonstration against it. Then on May 25, 1989, one million people, including students, workers, journalists, teachers, and government officials, demonstrated against martial law. This was the last large-scale demonstration before the movement was suppressed by the government on June 4, 1989 . One significant aspect of the movement was that from early May 1989, the students were joined by people from many professions. On more than one occasion, journalists, police officers, and government officials participated in the demonstrations. The non-student groups' participation pushed forward the pro-democracy movement, changing it from a student movement to a large-scale people's pro-democracy movement. 
The Press Coverage of the Movement

The research findings concerning the second research question ("what are the changes in the press coverage of the movement?") suggest that the People's Daily paid increasing attention to the pro-democracy movement throughout the research periods. First, there was no coverage of the movement in the People's Daily before April 20, 1989. At the same time, the movement received some attention from the Science and Technology Daily and the World Economic Herald. Second, news coverage of the movement in the People's Daily increased sharply from mid-May to late May 1989 (see Figure 3, p. 42). Third, after the imposition of martial law in Beijing on May 20, 1989, news coverage continued to increase in the People's Daily. Finally, news coverage of the movement in the People's Daily increased dramatically after the military suppression of the movement.

Research findings regarding the different media terms used to describe the movement indicate that the attitude of the People's Daily towards the movement changed dramatically in different periods. The newspaper used negative, neutral, positive terms and the disparaging term "a handful of people" to refer to the movement. The negative terms that were most often used were "counterrevolutionary," "turmoil," and "rioters." These negative terms decreased in number from 79, in the first research period, to 21 , in the second research period. However, from the third research period to the last 
research period, negative terms increased sharply from 367 times to 1,330 .

The neutral terms found in the People's Daily were "student movement," "student demonstration," and "student protest." There was no use of neutral terms in the first research period. In the second research period, neutral terms were used most frequently, 188 times, as compared to the third research period, in which the number decreased to 33. In the last research period, no neutral terms were found in the People's Daily.

Positive terms were not found in the first research period. The use of positive terms jumped to 214 in the second research period, and decreased to 60 in the third research period. No positive terms were found in the last research period.

Besides using negative, neutral, and positive terms, the People's Daily also used the phrase "a handful of people" as a disparagement to the movement. In the first research period, the People's Daily used "a handful of people" 18 times to refer to the demonstrators. The use of this phrase decreased to 4 times in the second research period, and increased to 80 in the third research period. In the last research period, the use of this phrase increased sharply to 211 times.

Correspondence Between the Movement and News Coverage In the first research period, there was no close 
correspondence between the movement and news coverage in the People's Daily. When the demonstrations were on the rise at the beginning, the People's Daily ignored the movement. One week later, the newspaper began its negative coverage, using the phrase "a handful of people" to trivilize the movement (see Figure $7 \& 8$, p. 54). When there were no demonstrations at the end of April and in the first three days of May 1989, negative terms in the newspaper increased dramatically (see Figure 7, p. 54). This pattern can be seen as a microcosm of the last research period: after the movement wound up with government suppression, negative terms also increased rapidly (see Figure 13, p. 61).

Findings of the second research period show a close correspondence between the movement and news coverage of it. The People's Daily increased its coverage along with the development of the movement. Negative terms decreased in number from 79 to 21 in this period. Neutral terms were used 188 times. When the movement reached its climax, positive terms in the newspaper also increased to 214 (see Figure 11, p. 59). Moreover, the phrase "a handful of people" only appeared 4 times in this period.

In the third research period, findings show a great deal of deviation between the movement and news coverage. The use of negative terms increased from 21 to 367 in this period. At the same time, neutral terms dropped in number from 188 to 33 , positive terms decreased from 214 to 60 , and the 
phrase "a handful of people" increased from 101 to 211 , shortly after the declaration of martial law.

As stated previously, in the last research period, the People's Daily's use of negative terms increased after the movement was stopped by the government. This trend parallels the end of the first research period.

\section{CONCLUSIONS}

The Chinese news media played different roles in the pro-democracy movement. Based on the research findings, three inferences could be drawn from the present study.

The Chinese news media remained silent about the students' activities during the first week of the movement. Then, on April 21, 1989, the People's Daily began to report the student activities unfavorably. In the first report of the movement, the students were branded as troublemakers, and the newspaper downplayed the movement by saying that it was incited by "a handful of people." The students were said to shout counterrevolutionary slogans, which was a serious charge in China. In the following days, the People's Daily printed stories of "rioters" and "hooligans" in different cities in an effort to detract from the movement, as the Party desired. On April 26, 1989, in its editorial, the People's Daily officially denounced the movement as "a planned conspiracy, a turmoil...instigated by a handful of people." 
The second inference is that the chinese news media played a role in propelling the pro-democracy movement by giving sympathetic accounts of the movement in mid-May 1989 , before moderate Party leader Zhao ziyang lost power. The then Mayor of Beijing, Chen xitong, made the following comment when he criticized the news media after the movement was repressed:

... The People's Daily and many other national newspapers and periodicals adopted an attitude of full acknowledgment and active support of the demonstrations, sit-ins, and hunger strikes, devoting lengthy coverage with no less exaggeration (Mu \& Thompson, 1989, p. 134).

Berlin (1989) provided a similar comment when he said,

... What legitimised the demonstrators' slogans was that for a few weeks the state-owned newspapers, radio and television reported student actions and views in neutral and even positive terms (p. 33).

For a fews days in May 1989, the People's Daily, as the leading newspaper in China, played a positive role in the development of the pro-democracy movement. However, after June 4, 1989, the Chinese press fully resumed its original role as the mouthpiece of the Communist Party. The People's Daily played a role in criticizing and condemning the prodemocracy movement. Findings of the last research period support this conclusion.

From the end of May 1989 to early June 1989, the use of negative terms in the People's Daily increased dramatically, compared to previous research periods (see Figure 13, p. 61). 


\section{LIMITATIONS AND IMPLICATIONS}

There are two limitations to the present research that need to be made clear. One is that the People's Daily is only one of the Chinese newspapers that are published and distributed by the chinese government, though it is the most authoritative political paper in China. It would be ideal to conduct similar research on other chinese newspapers, (like Guangming Ribao, Wenhui Pao, the Science and Technology Daily, etc.) to see if these findings would support the findings in this study. Second, due to limitations of time and available research facilities, the span of this study only includes the 1989 pro-democracy movement. Longitudinal research on the same subject would yield intriguing findings regarding the role of the chinese news media in sociopolitical movements after 1949.

From the research findings of this study, there is no factual evidence that shows a causal link between changes in the pro-democracy movement and changes in the press coverage of it. Therefore, I cannot claim that the chinese news media changed the pro-democracy movement or that the movement caused the changes in the news media's coverage of it, when, for example, during the second research period, the media exactly corresponded with the development of the movement. On the other hand, the contribution of this study is that it provides evidence of validity for other's claims. 
REFERENCES

BOOKS AND JOURNAL ARTICLES

Barelson, B. (1952). Content analysis in communication research. New York: Free Press.

Berlin, M. J. (1989). Chinese journalists cover and join the revolution. Washington Journalism Review. Sept. 1989, 33-37.

Chan, A. (1990). The challenge to the social fabric. In David Goodman \& Gerald Segal (Ed.), China at forty: Midlife crisis? Clarendon Press, Oxford.

Chu, G. C. (1981). The current structure and functions of China's mass media. In Cleveland wilhoit (Ed.), Mass Communication Review Yearbook. 738-759.

Elston, W. E. (1972). In China, newspapers serve the Party, in China Today. Detroit: Detroit News, 52.

Ethridge, J. (1990). China's unfinished revolution: Problems and prospects since Mao. China Books \& Periodicals, Inc San Francisco.

Feigon, L. (1990) . China rising: The meaning of Tiananmen. Ivan R. Dee, Publisher, Chicago.

Gans, H. (1979). Deciding what's news. New York: Pantheon.

Gitlin, T. (1980). The whole world is watching. London: University of California Press Ltd.

Hsiao, C. \& Yang, M. (1990). Don't force us to lie: The case of the World Economic Herald. In Chin-chuan Lee (Ed.), Voice of China. The Guilford Press, New York.

Hsu, P. (1990). China without Mao: The search for a new order. Oxford University Press, New York.

Howitt, D. (1982). The mass media and social problems. Pergamon Press.

$\mathrm{Hu}, \mathrm{Y}$. B. (1985). On our Party's journalism. China Daily, April 15, 1985. 1 .

Krippendorff, K. P. (1980). Content analysis: An 
introduction to its methodology. Sage Publications, Inc.

Lang, K. \& Lang, G. (1953). The unique perspective of television and its effects: A pilot study. In w. Schramm (Ed.), Mass communication. Urbana, Illinois: university of Illinois Press.

Lazarsfeld, P. \& Merton, R. (1960). Mass communication, popular taste and organized action. In Wilbur Schramm (Ed.), Mass communication. University of Illinois Press, Urbana.

Lee, C. C. (1990). Mass media of China, about China. In Chin-chuan Lee (Ed.), Voice of China. The Guilford Press, New York.

Lee, C. C. (1990). The Hong Kong Press in China's Orbit: Thunder of Tiananmen. In Chin-chuan Lee (Ed.), Voice of China. The Guilford Press, New York.

Lin, C. \& Salwen, M. B. (1987). Three press systems view Sino-U.S. normalization. Journalism Quarterly. 63, 360-365.

Liu, B. Y. (1989). Tell the world. Pantheon Books, New York.

Mao, Z. D. (1966). Get organized. Selected works of Mao Zedong. Vol 3, 158 .

Mao, Z. D. (1969). A talk to the editorial staff of the Shansi-Suiyuan Daily. Selected Works of Mao Zedong. Peking: Foreign Language Press, Vol 3, 24.

Min Pao News. (1989). June Fourth: A chronicle of the Chinese democratic uprising by the photographers and reporters of the Min Pao News. The university of Arkansas Press, Fayetteville.

Mu, Y. \& Thompson, M. V. (1989). Crisis at Tiananmen: Reform and reality in modern China. China Books \& Periodicals, Inc, San Francisco.

Nathan, J. A. (1979). Mass mobilization and political participation in China: Do people believe the media? A paper presented at the conference on communication and societal integration in China. East-West Center, Honolulu, Hawaii.

Nathan, J. A. (1985). The media in the service of the state. Chinese democracy. Alfred A. Knopf Inc, New York. 
Phifer, G. (1961). The Historical Approach, in Clyde Dow (Ed.), An introduction to graduate study in speech and theatre. Michigan State University Press, 52-80.

Polumbaum, J. (1986). The tribulations of China's journalists after a decade of reform. In Chin-chuan Lee (Ed.), Voice of China. The Guilford Press, New York.

Pye, L. W. (1978). Communication and China political culture. Asian Survey. 18, 221-246.

Remington, T. F. (1988). Truth and authority: Ideology and communication in the Soviet Union. University of Pittsburge, 136.

Rubin, R. B., Rubin, A. M., \& Piele, L. T. (1986). Communication research: Strategies and sources. Belmont, CA: Wadsworth.

Rosenthal, A. M. (1989). The truth of china. The New York Times. May 23, 1989, A-29.

Saich, T. (1990). When worlds collide: The Beijing people's movement of 1989. In Tony Saich (Ed.), The Chinese people's movement: Perspectives in spring 1989. M. E. Sharpe, Inc. New York.

Shen, T. (1990). Almost a revolution. Houghton Mifflin Company, Boston.

Siebert, F. S., Peterson, T. B. \& Schramm, W. (1956). Four theories of the press. Urbana: University of Illinois Press.

Sigal, L. V. (1986). Sources make the news. In Manoff \& Schudson (Ed.), Reading the news. New York: Pantheon Books.

Simmie, S. \& Nixon, B. (1989). Tiananmen Square. University of Washington Press, Seattle.

Stacks, D. W., \& Hocking, J. E. (1992). Essentials of communication research. Harper Collins Publishers.

Sun, J. (1992). The 1989 Chinese pro-democracy movement and the U.S. media. unpublished graduate thesis, Portland State University.

Terrell, R. L. (1984). Modernization and the media in China. Gazette, 33, 143-154.

Tuchman, G. (1978). Making news: A study of the construction 
of reality. New York: Free Press.

Walder, A. (1986). Communist neo-traditionalism: Work and authority in Chinese industry. University of California Press, Berkeley.

\section{ARTICLES FROM THE PEOPLE'S DAILY}

Jie Yan Bu Dui Gei Beijing Shi Min de Yi Feng Xin.

A letter to the citizens in Beijing by the martial law army. (1989, May 22) p.1.

Beijing Shi Suo Gao Xiao Xiao zhang Gei zheng Fu de Gong kai Xin.

An open letter to the government leaders by ten presidents of Beijing colleges and universities. (1989, May 17) p. 2.

Chen Xitong Dui Beijing Shi Min de Guang Buo Jiang Hua.

Chen Xitong's broadcasting speech to Beijing citizens. (1989, June 5) p. 1 .

Li Peng Zai Dang zheng Jun Ling Dao Tong Zhi Hui Yi Shang de Jiang Hua.

Li Peng's speech at a meeting attended by top party, government and military leaders. (1989, May 20) p. 1.

Wen Ding Shou Du He Quang Guo de zhong Yao Cuo Shi.

Important measures to stabilize the capital and the nation. (1989, May 22). p. 1 .

Shou Du Bai Wan Yu Ren You Xin Zhi Chi Jue Shi Xue Shong.

One million people from all walks of life demonstrate in support of hunger-striking students. (1989, May 18). p. 1 .

Jiu Jiu Xue Shong Jiu Jiu Hai zhi.

Save the students, save the children. (1989, May 18) p. 1 . Yi Xie Xue shong Zai Xin Hua Men Qian zhi Zao Shi Duan.

Some students created troubles in front of Xinhua Gate. (1989, April 21) p. 1 .

Xin Wan Jie Xiang Zheng Fu Ti Chu San Dian Yao Qui. 
Some news reporters made three demands to the government. (1989, May 19) p. 2 .

Bi Xu Qi Zhi Xian Ming di Fan Dui Dong Luang.

Take a clear-cut stand against turmoil. (1989, April 26). p. 1 .

Biejing Shi Zheng Fu Di Yi Fa Ling.

The first decree of Beijing city government. (1989, May 21 ). p. 1 .

Zhong Guo Zuo Xie Ken Qing Zheng Fu Li Ji Yu Xue sheng Dui Hua .

The Chinese writers' association pleads for the government to talk to the students immediately. (1989, May 19). p. 2 .

Qi sheng Zheng Fu Zhi Chi zhong Yang de Xin.

Letters from seven provincial government committees supporting the central government. (1989, May 22). p. 1 .

Beijing Fan Ge Ming Bao Luang de Shi Shi zheng Xiang.

The real story of the counterrevolutionary rebellion in Beijing. (1989, June 10). p. 1 . 


\section{APPENDIX A}

\section{CODING SHEET A: ATTENTION TO THE MOVEMENT}

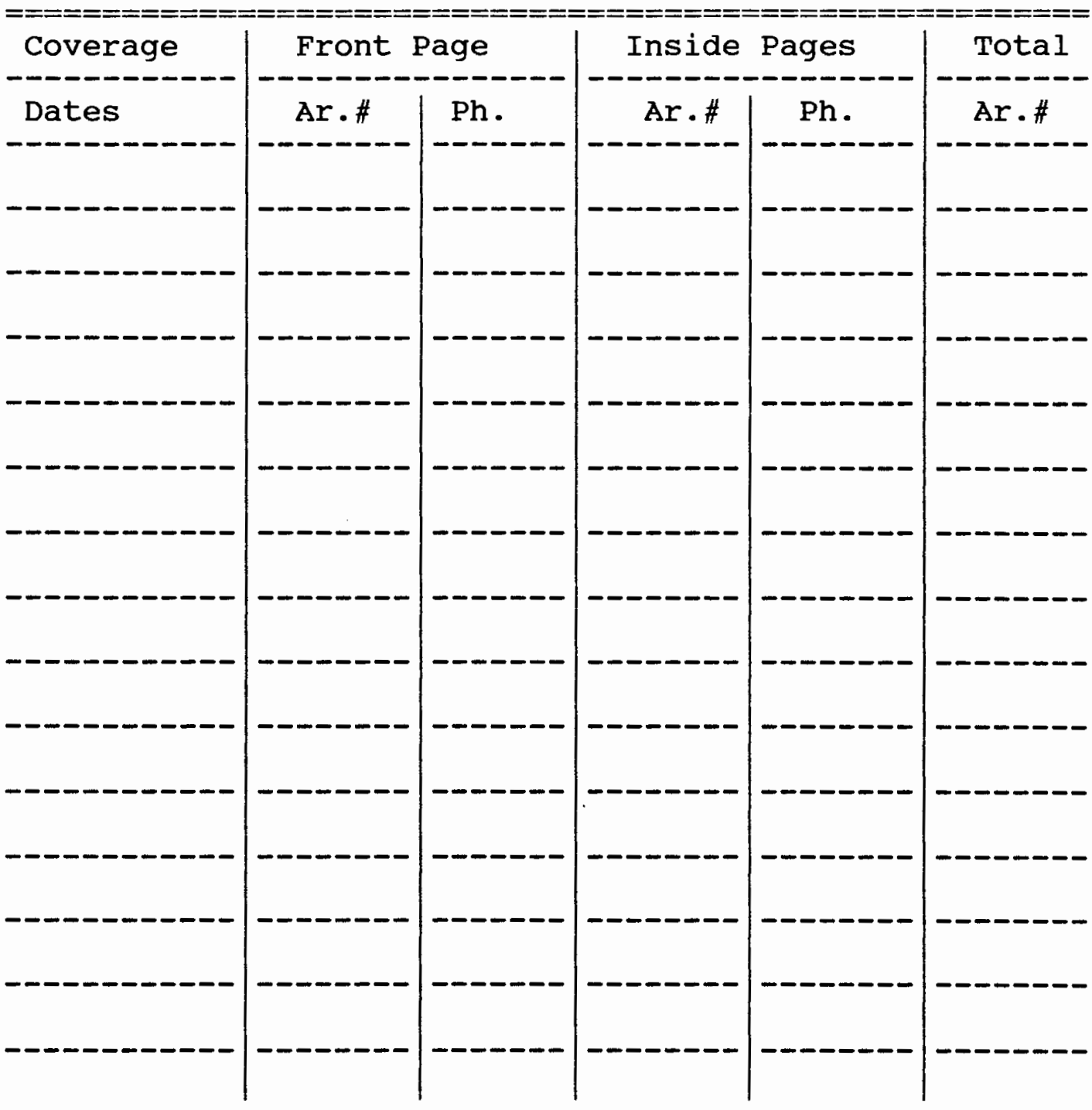

NOTES : 


\section{CODING SHEET B: SYMBOLIC TERMS}

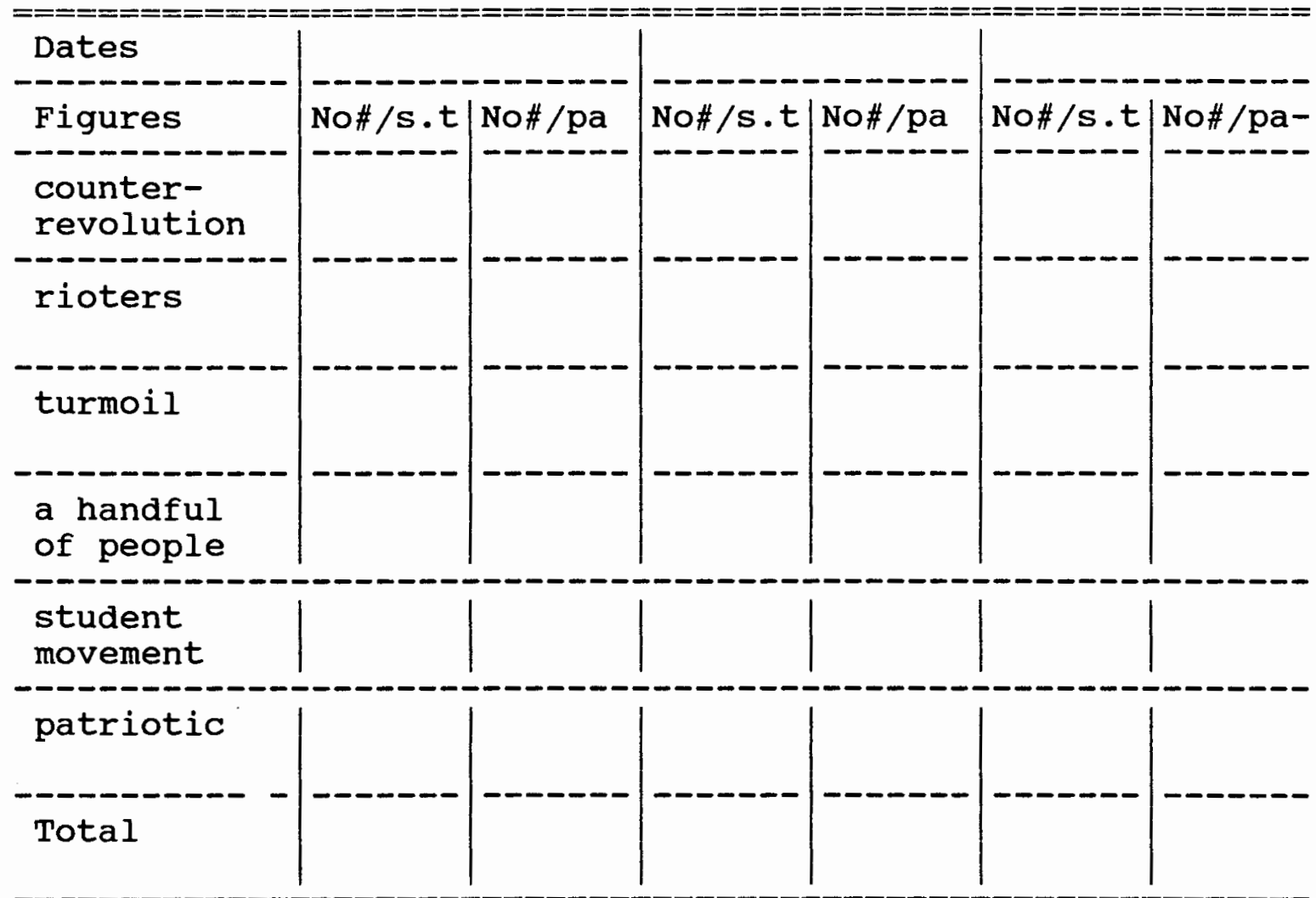

*indicates the number of paragraphs from which symbols are drawn.

No./s.t stands for number of symbolic terms.

Counterrevolution includes anti-party, anti-socialist system, and illegal.

Rioters include hooligans, trouble-makers and instigators.

Turmoil includes political disturbance, rebellion, comparing the movement to the cultural Revolution.

A handful of people includes very few people, a small number of people.

student movement includes student demonstrations, student protests.

Patriotic includes peaceful, legal, nonviolent, popular. 